\title{
Review \\ Understanding the Role of Protein Glycation in the Amyloid Aggregation Process
}

\author{
Ivana Sirangelo (D) and Clara Iannuzzi *(D) \\ Department of Precision Medicine, Università degli Studi della Campania "Luigi Vanvitelli", Via L. De Crecchio 7, \\ 80138 Naples, Italy; ivana.sirangelo@unicampania.it \\ * Correspondence: clara.iannuzzi@unicampania.it
}

check for

updates

Citation: Sirangelo, I.; Iannuzzi, C. Understanding the Role of Protein Glycation in the Amyloid Aggregation Process. Int. J. Mol. Sci. 2021, 22, 6609. https://doi.org /10.3390/ijms22126609

Academic Editor: Cláudio M. Gomes

Received: 25 May 2021

Accepted: 16 June 2021

Published: 21 June 2021

Publisher's Note: MDPI stays neutral with regard to jurisdictional claims in published maps and institutional affiliations.

Copyright: (C) 2021 by the authors Licensee MDPI, Basel, Switzerland. This article is an open access article distributed under the terms and conditions of the Creative Commons Attribution (CC BY) license (https:// creativecommons.org/licenses/by/ $4.0 /)$

\begin{abstract}
Protein function and flexibility is directly related to the native distribution of its structural elements and any alteration in protein architecture leads to several abnormalities and accumulation of misfolded proteins. This phenomenon is associated with a range of increasingly common human disorders, including Alzheimer and Parkinson diseases, type II diabetes, and a number of systemic amyloidosis characterized by the accumulation of amyloid aggregates both in the extracellular space of tissues and as intracellular deposits. Post-translational modifications are known to have an active role in the in vivo amyloid aggregation as able to affect protein structure and dynamics. Among them, a key role seems to be played by non-enzymatic glycation, the most unwanted irreversible modification of the protein structure, which strongly affects long-living proteins throughout the body. This study provided an overview of the molecular effects induced by glycation on the amyloid aggregation process of several protein models associated with misfolding diseases. In particular, we analyzed the role of glycation on protein folding, kinetics of amyloid formation, and amyloid cytotoxicity in order to shed light on the role of this post-translational modification in the in vivo amyloid aggregation process.
\end{abstract}

Keywords: amyloid aggregation; protein glycation; AGEs; protein misfolding; amyloidosis

\section{Introduction}

The increase in life expectancy observed over the last century has led to the appearance of a new set of pathologies that constitute new challenges to scientists and clinicians. Among these, neurodegenerative disorders like Alzheimer's, Parkinson's, and prion diseases are debilitating and incurable disorders with an increasing impact on society, because the number of diagnosed patients has dramatically increased over the past twenty years and it is expected to further increase in developing countries [1,2]. The histological hallmark of these disease is the presence of proteinaceous aggregates, which form deposits called amyloid plaques that usually accumulate both in the extracellular space of tissues and as intracellular deposits [3,4]. Although the amyloid aggregation process of the proteins involved has been widely characterized in vitro, the molecular mechanisms underlying the formation of amyloid species in vivo and in pathological conditions are still poorly understood. In this respect, post-translational modifications are known to have an active role as able to affect protein structure and dynamics [5,6]. Among them, a key role seems to be played by non-enzymatic glycation, an irreversible modification of the protein structure, which strongly affects long-living proteins throughout the body [7,8]. Indeed, proteins in amyloid deposits are often found glycated in patients, thus suggesting a direct correlation between protein glycation and amyloidosis [9-12]. For this reason, much attention has been paid to the role played by non-enzymatic glycation in promoting amyloid aggregation and cytotoxicity. This study provided an overview of the molecular effects induced by glycation on the amyloid aggregation process of several protein models associated with misfolding diseases in order to shed light on the role of this post-translational modification in the in vivo amyloid formation. 


\section{Protein Glycation}

During their lifetime, proteins are exposed to several altering factors, including enzymatic and non-enzymatic mechanisms. Among the non-enzymatic mechanisms, protein glycation is one of the most important post-translational modification in which protein is covalently modified through the addition of functional groups to its amino-acid residues $[13,14]$. This process is different from glycosylation which is a selective protein modification driven by specific enzymes, generally associated with a gain of function (or stabilization) of the target protein. Differently, non-enzymatic glycation is a non-selective modification and it is generally associated with a loss of function of the target protein due to modifications of its native structure.

Glycation reaction is a naturally occurring process common to all cell types: Glycated products slowly accumulate in vivo leading, in addition to cellular modifications involved in the aging process, to several different protein dysfunctions $[8,15,16]$. Protein glycation is initiated by a spontaneous nucleophilic addition reaction between the free amino group of a protein, generally belonging to $\mathrm{N}$-terminal and lysine side chain, and the carbonyl group of a reducing sugar. This reaction rapidly forms a reversible Schiff base, which rearranges over a period of weeks to produce ketoamine or Amadori product. This reaction is reversible depending on the concentration of the reactants. Thereafter, the Amadori product undergoes an irreversible cascade of reactions involving dehydration, hydrolysis, and rearrangements leading to the formation of advanced glycation end products (AGEs) (Figure 1) [17,18].
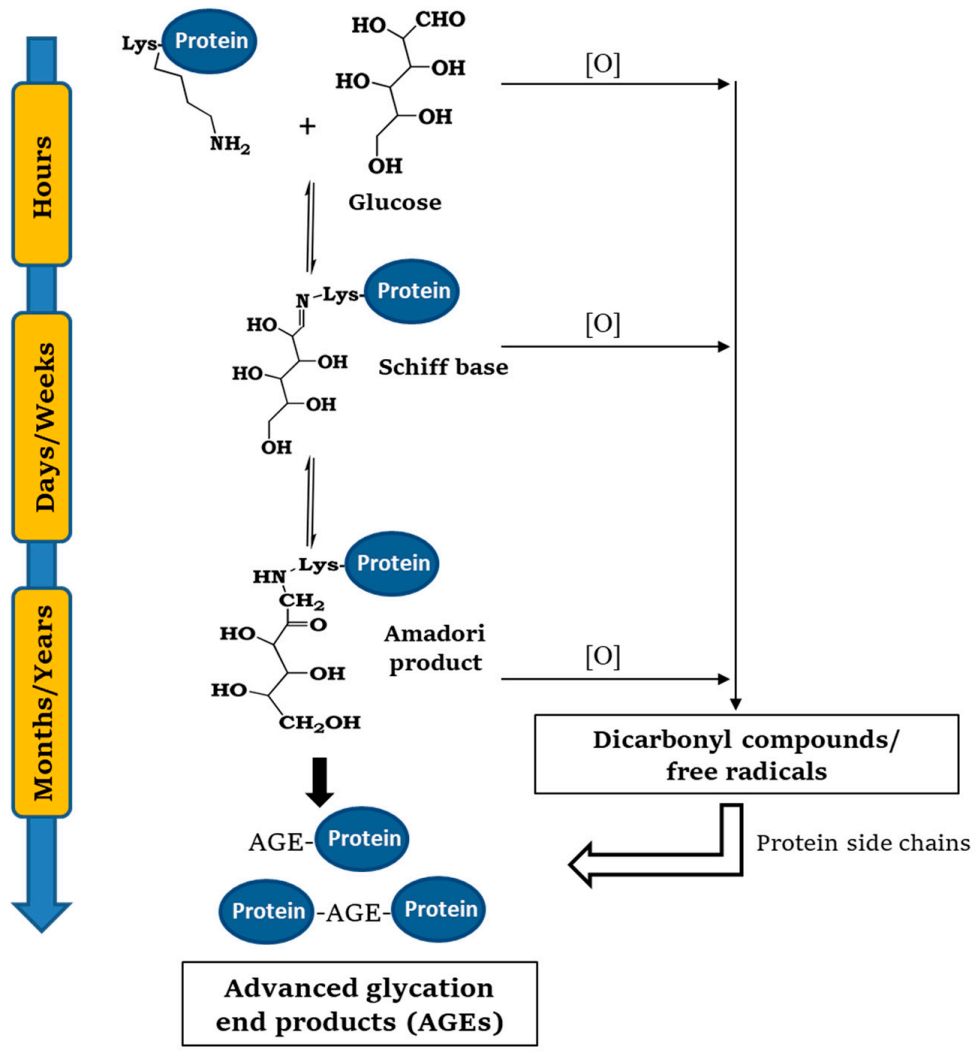

Figure 1. General mechanism of protein glycation. The process is initiated by a spontaneous nucleophilic addition reaction between the free amino group of a protein, generally belonging to $\mathrm{N}$-terminal and lysine side chain, and the carbonyl group of a reducing sugar. This reaction rapidly forms a reversible Schiff base, which rearranges over a period of weeks to produce ketoamine or Amadori product. The Amadori product undergoes an irreversible cascade of reactions involving dehydration, hydrolysis, and rearrangements leading to the formation of advanced glycation end products (AGEs). 
Although the formation of the Schiff base and the Amadori product constitutes the central pathways along this mechanism, the whole process becomes much more complex due to collateral autoxidative reactions of reducing sugars, Schiff bases, and the Amadori product. In particular, these reactions produce highly reactive carbonyl species and free radicals that can further react with free amino acid side chains contributing to the AGEs formation $[19,20]$ (Figure 1). In fact, although glycation can be started by all reducing sugars, the activity of dicarbonyl compounds like glyoxal (GO) and methylglyoxal (MGO) in the reaction is much higher even at negligible concentrations [20]. The main targets of protein glycation are side-chains of arginine and lysine residues, the $\mathrm{N}$-terminus amino group, and thiol groups of cysteine residues. The kinetics of the process depends on several conditions: concentration and reactivity of the glycation agent, the presence of catalytic factors (metals, buffer ions, and oxygen), $\mathrm{pH}$, temperature, exposure of glycating sites, and half-life of the protein. All reducing sugars can promote glycation reactions and, between them, D-ribose is the most active, while D-glucose, glucose 6-phosphate, mannose, and fructose are much less reactive [16,21].

Glycated species are very heterogeneous and generally classified in cross-linking and non-cross-linking AGEs on the basis of their ability to form covalent cross-links, both intra- and inter-molecular, within the polypeptide chains (Figure 2). AGEs accumulate slowly throughout lifetime and are considered a marker for several diseases, such as arteriosclerosis, renal failure, Alzheimer disease, or diabetes, although they normally increase in aging [22]. In fact, due to their chemical, pro-oxidant, and inflammatory activities, clear evidence suggests the involvement of modified AGE proteins in degenerative disorders such as neurodegenerative pathologies, cardiovascular disease, and diabetes complications [23-25]. At the cellular level, AGEs can contribute to these pathologies in two different ways: (1) by binding specific receptors on cell membrane, mainly the receptor for advanced glycation end-product (RAGE), which trigger inflammatory and oxidative processes implicated in the pathogeny of several diseases processes, and (2) through an independent-receptor manner, cross-linking proteins and altering their structure, properties, and functions $[18,26]$. Indeed, as positively charged Lys and Arg residues are the preferential glycating sites, modifications at these residues not only affect their local microenvironment and the protein charge, but also shield them from the formation of hydrogen bonds that stabilize the protein structure. In addition, formation of covalent cross-links within different polypeptides strongly contribute to modify protein structure thus affecting its physiological function.

Moreover, glycation at lysine residues would also impair the clearance by the ubiquitinproteasome system because ubiquitination of lysine residues, a modification that targets the protein to the proteasome for degradation, would be prevented in glycated proteins. In this respect, protein glycation, besides affecting protein structure and function, might also favor accumulation of proteins as aggregates or inclusion in tissues [27-29]. 


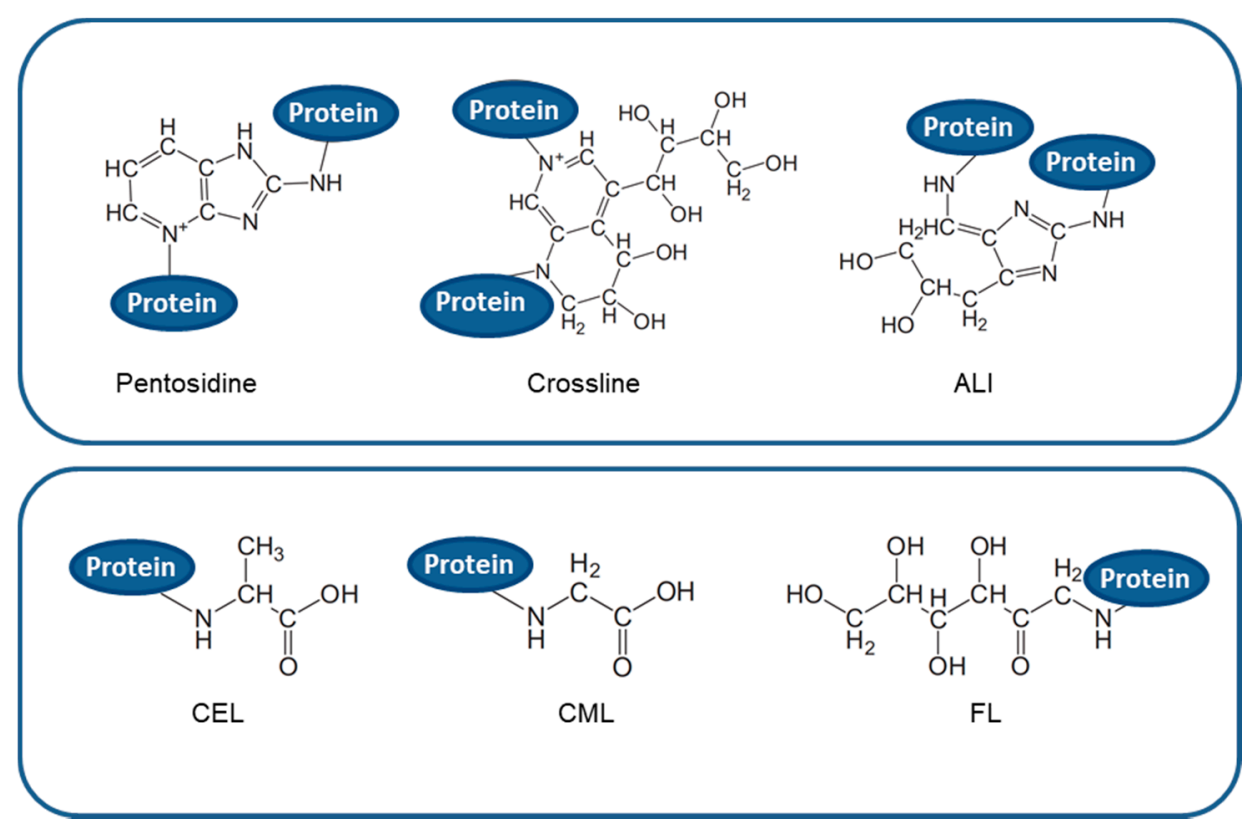

Figure 2. Chemical structure of different type of AGEs. Upper panel: cross-linking AGEs such as pentosidine; crossline; and ALI: arginine-lysine imidazole cross-links. Lower panel: non-cross-linking AGEs such as CEL: N-carboxyethyl-lysine; CML: N-carboxymethyllysine; and FL: N-fructosyl-lysine.

\section{Amyloid Aggregation Process}

The conversion of native soluble proteins into insoluble amyloid deposits has attracted considerable interest in the last decades as associated with several disorders known as "amyloid diseases". So far, there are approximately 50 disorders, with a multitude of symptoms, associated with the misfolding of soluble, functional proteins or peptides, and their following conversion into amyloid fibrils $[3,30,31]$. This wide range of diseases includes neurodegenerative disorders like Alzheimer's, Parkinson's, and prion diseases, as well as non-neuropathic conditions such as type II diabetes [3,4,32]. With the increase of life expectancy, these disorders are no longer rare, but are rapidly becoming among the most common and debilitating medical conditions. In these diseases, the physiological alterations are associated with the formation of fibrillar aggregates, known as amyloid fibrils, which regardless of the protein involved, share a common ultrastructure $[33,34]$. These protein aggregates interfere with neuronal function and induce toxicity that ultimately drives cell death. Amyloid aggregates usually accumulate both in the intra- and extracellular space and promote a dual toxicity: loss of natural protein function mechanism (by improper folding, degradation or localization) and/or gain of toxic novel functional mechanism (toxic structures that accumulates in an incorrect location) [35,36].

The formation of amyloid structures is not a rare phenomenon and it reflects a welldefined structural form of the protein that is an alternative to the native state, a form that may in principle be adopted by many, if not all, polypeptide sequences $[3,37,38]$. Indeed, it is now believed that many, if not all, proteins can form amyloid fibrils in appropriate experimental conditions. This is because protein folding and protein aggregation, although being distinct processes, are in competition and the environmental conditions can instruct polypeptide chains on the conformation to adopt. Extensive studies have been performed in vitro to shed light on the structural transitions between natively folded states and amyloid-aggregation prone states. Natively folded globular proteins possess a small but significant tendency to convert into the amyloid state without crossing a major energy barrier for unfolding, by populating native-like conformations as a consequence of local unfolding, thermal fluctuations, or ligand release. The dangerous aggregation-prone states, although quite similar to the native state, seem to display altered surface charge 
distribution, alternative $\beta$-sheet topology, increased exposure of hydrophobic surfaces, and aggregation-prone sequences of the polypeptide chain [39-41]. The formation of the aggregation-prone conformation has been well characterized in vitro for different model proteins and it has been shown to be promoted by low $\mathrm{pH}$, high temperature, high ionic strength, point-mutations, or organic solvents able to destabilize the native state [41-46].

The kinetics of amyloid aggregation originates with the formation of monomeric states, highly disordered, that possess an intrinsic propensity to further assembly into oligomeric species that are heterogeneous and highly reactive. The soluble oligomeric species rapidly evolve to the formation of insoluble protofibrils and, eventually, the fibril growth proceeds by further association of protofibrils [3,32] (Figure 3). The protein fibrils, regardless of the protein sequence and structure, share common properties such as a core rich in $\beta$-sheet structure adopting a characteristic cross- $\beta$ topology, the resistance to degradation and significant mechanical properties with high tensile strength. Thus, amyloid fibrils are highly resistant to in vivo degradation as extremely stable thermodynamically and thus difficult to unfold and processed by the proteasome. In addition, their thermodynamic stability contributes to convert close native proteins into amyloid species $[47,48]$. While insoluble amyloid fibrils correlate with disease progression, the soluble oligomeric species are generally associated with cellular toxicity as able to interact with biological membranes. The mechanisms of cellular toxicity of amyloid oligomers include both the membrane disruption, resulting in calcium imbalance, mitochondrial dysfunction and intracellular reactive oxygen species, as well as the direct interaction with membrane proteins, leading to the alteration of their native function $[30,49]$.

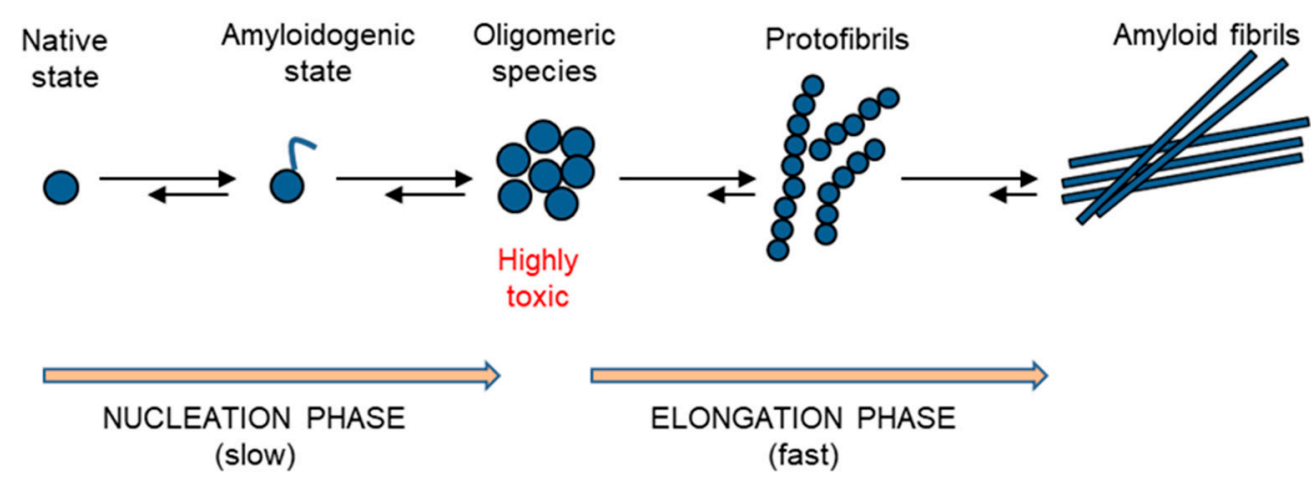

Figure 3. Schematic representation of the amyloid aggregation process. The process originates with the formation of amyloidogenic states, which are highly disordered and which possess an intrinsic propensity to further assembly into oligomeric species that are highly reactive (nucleation phase). The oligomeric species rapidly evolve to the formation of insoluble protofibrils and, eventually, the fibril growth proceeds by further association of protofibrils (elongation phase).

Although the molecular mechanisms underlying the amyloid formation has been well characterized in vitro, poor information is available on the molecular determinants that trigger amyloid formation in vivo. Post-translational modifications such as phosphorylation, nitration, acetylation, methylation, and glycation are known to have an active role in protein aggregation as they are able to affect protein structure and function $[6,7]$. Clearly, the understanding of the molecular mechanisms that trigger formation and propagation of amyloid species in vivo is a prerequisite for developing new treatment options for amyloidosis.

\section{Glycation Role in Amyloid Aggregation}

Although the amyloid aggregation process has been widely studied in vitro for different amyloidogenic proteins, and many physiological (environmental and genetic) factors involved have been identified, the molecular mechanisms underlying the amyloid formation in vivo and in pathological conditions are still poorly understood. Most neurodegenerative diseases are sporadic, suggesting that external factors might contribute to the onset and 
the progression of these disorders. Post-translational modifications are known to affect amyloid aggregation process as able to affect protein structure and function $[5,6]$. Among them, protein glycation seems to have a key role in amyloid formation both in vivo and in vitro. In addition, proteins in amyloid deposits are often found glycated in patients thus suggesting a direct correlation between protein glycation and amyloidosis [9-12]. In this respect, the effect of glycation in the amyloid aggregation process of proteins related to misfolding diseases has been widely studied in order to identify the role of glycation in the in vivo amyloid aggregation and cytotoxicity. In this study, we have analyzed the most recent advances in the field for different protein models.

\subsection{A $\beta$-Peptide}

Alzheimer's disease is characterized by the deposition in the brain of senile plaques, composed largely of the $\beta$-amyloid peptide $(A \beta)$. The $A \beta$ amyloid aggregation originates from an unstructured random coil conformation (monomeric form) that rapidly proceeds to $\beta$-sheet structure during aggregation (oligomers, protofibrils, fibrils) [50,51]. Although the $A \beta$-induced neurotoxicity is directly responsible for the pathology of $A D$, the in vivo toxic forms of $A \beta$-peptide remain poorly characterized. Non-enzymatic glycation seems to play a key role in the in vivo $A \beta$-toxicity. Indeed, the amyloid plaques in the AD brains are colocalized with AGEs and the plaque enriched fractions contain approximately threefold higher AGE adducts than that of the age-matched controls, suggesting that $A \beta$ may be glycated in $\mathrm{AD}[12,52,53]$. The long-live proteins are preferentially modified to form AGEs and the high stability of $\mathrm{A} \beta$ makes it an ideal substrate for non-enzymatic glycation and formation of AGEs. A role of blood sugars would also explain the link observed between the apparently unrelated diabetes and $\mathrm{AD}$; diabetic patients have a 2-5-fold higher tendency to develop AD compared with nondiabetic individuals [54-58].

To clarify the role of glycation in amyloid aggregation process of the A $\beta$-peptide, several studies have been performed in vitro on different AGE-derived A $\beta$-peptide. In particular, glycation of lysine residues has been shown to strongly affect oligomers stability, secondary structural content, structural disorder, and propensities of inter-peptide salt bridges [59]. The glycated peptide resulted in a more rigid assembly associated with a greater beta-sheet component, suggesting that glycation results in structural modifications of key self-assembling entities making them more aggregation prone [59]. In this study, it has been also explored the effect of glycation on the stabilities of pre-formed protofibrillar $\mathrm{A} \beta$-peptide species. Interestingly, glycation has been found to also induce major stabilizing effects on putative pre-formed protofibrillar structures corresponding to those found in brains of AD patients [59].

Differential effects of glycation between single-lysine and double-lysine CEL-modifications have been recently observed. Indeed, while little effect has been observed for single CELmodifications (Lys-16, Lys-18) in amyloid aggregation rate, a stronger effect has been obtained in the double lysine CEL-modifications. In particular, CEL-modifications at both Lys-16 and Lys-18 promote a substantial decrease in free energy change, which contributes to fibril destabilization, and an increased aggregation rate. In this respect, the amyloid aggregation of the double CEL-modified A $\beta$-peptide produced a lower amount of amyloid fibrils compared to the unglycated peptide and a higher percentage of soluble oligomers [60]. Similar results (reduced amount of amyloid fibrils and a higher concentration of oligomers) have been observed in the amyloid aggregation of $A \beta$-peptide glycated in the presence of MGO [61].

With regards to the role of glycation on the toxicity of $A \beta$ amyloid aggregates, only poor information is available. It is well established that the conformational state of this peptide is a key factor for its neurotoxicity. In particular, increasing evidence have suggested that the more toxic species for $A \beta$ are the soluble oligomers both in vitro and in vivo [62-68].

So far, different toxicity effects have been observed for glycated $A \beta$ aggregates accordingly to the glycating agent used. In particular, glycation performed with MGO has 
been shown to promote higher neurotoxicity of $A \beta$ aggregates although this effect seems not to be associated with amyloid aggregates but to a specific upregulation of RAGE by $A \beta$-peptide [53]. In fact, RAGE is known to possess a surface binding site both for AGE species and $A \beta$-peptide $[69,70]$. Differently, glycation performed with glucose, fructose and chondroitin sulfate has been shown to stabilize the fibrillar aggregates in $A \beta$ associated with very low toxicity [71]. Recent data performed on the double CEL-modified A $\beta$-peptide have shown that, although glycation stabilize the formation of soluble oligomers, lysine modification of $A \beta$ abolish its neurotoxicity, and this seems to be associated with the key role of these lysine residues in the binding of $A \beta$ with the cell membrane [60]. Even though further studies will be needed for a better understanding of the role of glycation in the toxicity of $A \beta$ aggregates, this seems to be strongly dependent on the structural modification induced by the glycating agents.

\section{2. $\alpha$-Synuclein}

$\alpha$-Synuclein ( $\alpha$-Syn) misfolding and aggregation is a hallmark in several neurodegenerative diseases including Parkinson's disease (PD) and dementia characterized by the presence of intraneuronal deposition of Lewy bodies (LB), and multiple system atrophy $[72,73]$. Although $\alpha$-Syn amyloid aggregates are known to be the main component of the LB, which cause the loss of dopaminergic neurons in the disease, there is no consensus on what mechanisms trigger $\alpha$-Syn in vivo aggregation, neuronal cell loss, and degeneration. Post-translational modifications such as glycation, sumoylation, and phosphorylation are known to be directly involved in $\alpha$-Syn misfolding and aggregation [10,74-76]. In particular, glycation seems to have a key role in $\alpha$-Syn aggregation as advanced glycation end-products (AGEs) and $\alpha$-Syn are co-localized in the brain of the patients at both the early and advanced stages of PD [10,77]. In addition, accumulation of AGEs on LBs becomes more relevant to people suffering from diabetes mellitus (DM), which could explain the increased prevalence of PD in DM patients $[78,79]$. Glycated $\alpha$-Syn also induces lipid peroxidation in vivo and results in lesions within cells $[80,81]$. For these reasons, glycation may play a key role in in the amyloid aggregation of $\alpha$-Syn associated with Lewy body formation in PD [10,76].

Normally in neurons, the $\mathrm{N}$-terminal domain of $\alpha$-Syn adopts an amphipathic $\alpha$ helical conformation that associates with membranes where it assembles into multimers [82-84]. This region is the one responsible for in vivo amyloid aggregation and, interestingly, it contains several lysine residues that can be glycated both in vitro and in vivo [85-88]. For this reason, several studies have been performed with different glycating agents in order to clarify the role of glycation in $\alpha$-Syn in vivo aggregation. In particular, glycation performed in the presence of D-ribose, MGO, and GO as glycating agents has been shown to strongly stabilize the N-terminal domain thus inhibiting amyloid fibril formation in $\alpha$-Syn. Despite restraining fibril formation, glycation was promoting the formation of stable cross-linked oligomeric species, able to induce oxidative stress and high cytotoxicity $[85,86,89]$. Most likely, the structure of this aggregates hinders further aggregation and makes the formation of amyloid fibrils difficult. The fact that glycation of $\alpha$-Syn leads to the formation of stable oligomers and inhibits fibril formation can be relevant for the study of synucleinopathies as $\alpha$-Syn oligomers are more toxic than larger aggregates [90,91]. Different results have been recently obtained in the CEL-modified $\alpha$-Syn that is unable to form both amyloid fibrils and oligomeric species [92]. In this study, the different behavior observed upon glycation could be due to the fact that the fifteen lysine residues in $\alpha$-Syn were synthetically modified with CEL moieties thus not able to form protein cross-links underlying the oligomers formation observed with D-ribose, MGO, and GO. The CEL-modifications were shown to strongly stabilize the $\alpha$-Syn structure and even the presence of zinc, able to induce amyloid aggregation in $\alpha$-Syn, was unable to promote aggregation in the CEL-modified protein [92].

Recently, the effect of glycation in $\alpha$-Syn has been investigated in vivo using different models [77]. This study has shown that glycation might play an important and underappre- 
ciated role in PD and other synucleinopathies by modulating $\alpha$-Syn biology. In particular, glycation is proven to also primarily affect the N-terminal region of $\alpha$-Syn in animal models, thus reducing its ability to bind to lipid membranes. In this way, glycation promotes $\alpha$-Syn accumulation and formation of oligomers that result as highly cytotoxic both in human cell lines and, importantly, in differentiated patient-derived iPSCs [77]. The toxic effects of glycation in $\alpha$-Syn aggregation were also detected in animal models of Parkinson's disease: $\alpha$-Syn transgenic drosophila and mice. Indeed, in $\alpha$-Syn expressing flies, glycation reduces both the motor performance and survival while in mice, MGO injection in the substantia nigra causes an impressive loss of neuronal cells. Besides stimulating the accumulation of toxic $\alpha$-Syn oligomers that impair neuronal synaptic transmission, glycation is proven to block $\alpha$-Syn ubiquitination thus also impairing its clearance and release [77]. Taken together, these findings confirm that glycation may perturb the physiological role of $\alpha$ Syn on vesicular trafficking by promoting protein accumulation and amyloid aggregation associated with LB.

\subsection{Insulin}

Insulin amyloid-like fibrils are the hallmark of a clinical condition observed in insulindependent diabetic patients, called insulin injection amyloidosis in which insulin fibrils are found at the site of insulin injections [93-95]. Native insulin is mainly organized in an $\alpha$-helical structure and its amyloid aggregation is proposed to occur via partial unfolding of a monomeric intermediate that promotes protein oligomerization and the $\alpha$ to $\beta$ transition underlying the amyloid formation [96-98].

Insulin is associated with glycemia and is susceptible to in vivo glycation by glucose and other highly reactive carbonyls especially in diabetic conditions [99-101]. When glycated, human insulin is unable to regulate glucose homeostasis and stimulate glucose transport and adipose tissue lipogenesis [102-104]. Indeed, glycation has been reported to affect insulin structure, stability and amyloid aggregation depending on glycating agent and/ or environmental conditions. Insulin can be glycated by glucose in vitro and glycated species possess different structural features depending on the experimental conditions used [105-107]. In particular, glycation in reducing conditions promotes insulin oligomerization thus accelerating amyloid aggregation, while, in non-reducing conditions, it strongly inhibits amyloid formation in a way proportional to the glycation extent [107]. Human insulin can be also glycated by MGO that promotes the formation of native-like species and reduces the ability of insulin to form amyloid fibrils by impairing the formation of the seeding nuclei. Although MGO reacts with a single residue in insulin (Arg22), it strongly stabilizes the native structure as glycated species are soluble, non-fibrillar and retain a native-like structure [108]. A similar effect has been observed when glycation is performed in the presence of D-ribose, able to react with $\mathrm{N}$-terminus and Lys29 in human insulin. Indeed, glycation by D-ribose strongly stabilize insulin native structure and impair the $\alpha$ to $\beta$ transition underlying the amyloid formation [109]. The overall data suggest that, at least in non-reducing conditions, glycation seems to have a protective effect in insulin amyloid formation as it is able to stabilize insulin-native structures, thus preventing amyloid aggregation. Moreover, as accumulation of AGEs has been suggested as one of the main responsible factors of diabetes-associated complications, such as retinopathy, nephropathy, and atherosclerosis, further examination of the molecular bases underlying the toxic effect produced by AGE-modified insulin on neighboring cells might help to identify new therapeutic interventions.

\subsection{Islet Amyloid Polypeptide}

The presence of amyloid fibrils in pancreatic $\beta$-cells, arising from the aggregation of human islet amyloid polypeptide (hIAPP), is a hallmark of type 2 diabetes (T2DM) [110,111]. hIAPP is a 37-residue natively unstructured polypeptide that is prone to aggregate into amyloid fibrils, thus inducing pancreatic $\beta$-cell dysfunction, cell death, and loss of islet $\beta$-cell mass. Therefore, the aggregation of hIAPP is considered one of the major causes 
of T2DM [112-117]. The amyloidogenicity of IAPP is very sensitive to residue changes or post-translational modifications including glycation [118-123].

hIAPP is likely to be glycated in vivo as AGE immunoreactivity colocalizes with regions of immunoreactive IAPP-derived amyloid and it has been proposed that AGEmodified IAPP acts as a template in the nucleation-dependent aggregation of IAPP into amyloid fibrils. In particular, in vitro glycation of IAPP with glucose has been shown to promote the formation of protein aggregates showing a better seeding efficiency than freshly dissolved IAPP and also exhibited higher cytotoxicity than control IAPP [118-120]. Similar data were recently obtained on the chemically synthesized AGE-IAPP by modification of Lys1, the only Lys residue, with carboxymethyl-lysine (CML) AGE [124]. Indeed, this CML-modified IAPP was forming amyloid aggregates faster than non-modified IAPP, and higher molecular weight AGE-IAPP oligomers were also observed in the early stage of aggregation. In addition, AGE-IAPP can promote amyloid aggregation in non-modified IAPP, and its fibrils can also act as templates to trigger IAPP aggregation. Moreover, the AGE-modified IAPP, such as normal IAPP, is able to interact with synthetic membranes and also to exhibit cytotoxicity [124]. Recently, glycation of IAPP has been studied in the presence of MGO as glycating agent [125]. In this study, MGO has been shown to efficiently react only with IAPP Lys1 inducing both a slowdown of the IAPP aggregation process and changes in the aggregate morphology [125]. This study suggests that, although the only AGE-modified residue is Lys1 as in the CML-derived IAPP, differences in the AGEs produced and in the experimental conditions may play a key role in the dynamic effects induced by glycation on the aggregation process. The overall data suggest that glycation modifications of hIAPP might strongly modulate the amyloidogenic properties of this protein, and this could play a key role in accumulating additional amyloid during T2DM progression.

\subsection{Albumin}

Human serum albumin (HSA), the most abundant serum protein with versatile applications both in vivo and in vitro, has been a widely used model for understanding the structural effects of glycation as it contains 83 potential glycation sites (59 lysine and 23 arginine residues, $\mathrm{N}$ terminus) [126-129]. Glycated HSA accounts for $80 \%$ of the circulating glycated protein and it has been implicated in several complications associated with diabetes [130-132]. Although HSA is a highly soluble protein mainly organized in $\alpha$-helical structure, it is able to form amyloid fibrils through partial unfolding of the tertiary structure and conformational changes of the secondary structure [133-135]. In addition, this protein can be efficiently glycated in vitro by several glycating agents as glucose, Dribose, MGO and GO and similar effects on the amyloid propensity have been observed with all of them [126-128,136-138]. In particular, glycation has been shown to promote strong conformational changes in HSA that affect both secondary and tertiary structure and markedly reduce the protein stability. In this way, glycation promotes amyloid aggregation in HSA both reducing the helical content and supporting the formation of $\beta$-cross structure that rapidly evolve to the formation of amyloid aggregates [129,139-141]. Interestingly, glycation of albumin performed in the presence of D-ribose, besides promoting amyloid formation, has been shown to stabilize the amyloid oligomeric species that result highly cytotoxic in neuronal cells [129]. Indeed, amyloid aggregates of ribosylated albumin were able to induce oxidative stress ROS-mediated and apoptosis in neurotypic cells. The overall data suggest that non-enzymatic glycation reaction could have a key role in the in vivo BSA glycation as both promoting amyloid formation and stabilizing toxic oligomeric species.

\subsection{Superoxide Dismutase 1}

Amyloid aggregation of copper, zinc superoxide dismutase SOD1, an essential component of the cellular antioxidant defense system, is associated with amyotrophic lateral sclerosis (ALS), a neurological disease causing the death of motor neurons and muscular 
paralysis. ALS it is predominantly a sporadic disease, in some cases $(10 \%)$ it has been described as familial [142-144].

In vitro studies have shown that human SOD1, when lacking both its metal ions (ApoSOD), forms amyloid aggregates under physiological conditions of $\mathrm{pH}$ and temperature. Indeed, loss of metal binding not only induces protein unfolding and loss of enzymatic activity in SOD1, but also promotes amyloid formation [145-149]. Although the molecular mechanisms underlying amyloid aggregation of SOD1 has been widely studied in vitro, poor information is available on the mechanism that trigger amyloid formation in vivo and in the pathological conditions of ALS.

In this respect, SOD1 glycation seems to have a determining role both in sporadic and familial forms of ALS; in fact, spinal cord and brain samples have been found to be glycated in patients $[150,151]$. Moreover, SOD1 has been shown to be glycated in vivo and glycation sites have been identified and they are six lysine residues (number 3, 9, 30, 36, 122, 128) spread along the protein sequence [152]. SOD1 glycation has been studied in vitro in the presence of different glycating agents and the effects of glycation in amyloid aggregation has been also evaluated [153-155]. In particular, SOD1 can be efficiently glycated in vitro by glucose, D-ribose, GO, and MGO and glycation was shown to promote protein unfolding, loss of copper binding and inhibition of the enzymatic activity [154,156-158]. These results have been confirmed by ex vivo experiments reporting that SOD1 extracted from erythrocytes of diabetic patients was significantly more glycated and has a lower enzymatic activity, with respect to controls [159]. Although promoting SOD1 unfolding and loss of metal binding, glycation has been shown to inhibit amyloid aggregation in SOD1 and promote the formation of stable cross-linked AGEs $[153,155]$. Taken together, these results suggest that glycation, besides having protective role in SOD1 amyloid aggregation, could impair the correct maturation of SOD1 in vivo as promoting protein unfolding, demetallation, and loss of enzymatic activity, thus triggering cellular oxidative stress.

\subsection{Lysozyme}

Amyloid aggregation of human lysozyme is responsible for lysozyme amyloidosis, a non-neuropathic hereditary amyloidosis in which protein mutations favor the formation of misfolded conformers which in turn leads to lysozyme aggregation and accumulation of amyloid deposits in several organs [160-164]. Hen egg white lysozyme (HEWL), a structural homolog of human lysozyme, has been widely used to study the amyloid aggregation of lysozyme in vitro. Wild-type HEWL is a globular protein with antibacterial activity and has a low aggregation tendency under physiological-like conditions, although it can form amyloid fibrils in denaturing conditions able to destabilize the native structure of the protein [165-168]. At the same time, this protein possesses six Lys as potential glycation sites and, for this reason, HEWL represents an ideal model to study if glycation per se induces amyloid aggregation.

HEWL has been shown to be susceptible to glycation by several glycation agents, such as D-glucose, D-ribose, D-fructose, and MGO [169-171]. Glycation strongly affects the structure of HEWL and inhibits its enzymatic activity thus increasing the susceptibility to bacterial infections [172,173]. Moreover, glycation affects the amyloid aggregation process of HEWL. Generally, glycation promotes the formation of oligomeric aggregates in HEWL but the mechanism underlying the process depends on the chemical nature of the glycating agent due to the different residues involved in the AGEs formation.

At first, the effect of glycation on HEWL aggregation has been studied using Dglucose, D-fructose and D-ribose as glycating agents and glycation was found to promote the formation of oligomeric species stabilized by covalent cross-links [174,175]. In these studies, it was hypothesized that glycation was inducing partial unfolding in HEWL promoting the $\alpha$-to $\beta$-transition underlying oligomeric formation. However, through a more detailed study, it has been shown that HEWL ribosylation involves a chemical multistep conversion that induces covalent modifications on lysine side chains without altering the protein structure but changing the protein charge and enlarging its hydrophobic 
surface. The increase of surface hydrophobicity triggers the assembly of ribosylated HEWL into native-like small spherical oligomers highly toxic, which further evolve into insoluble native-like protofibrils [176].

The glycation of HEWL has been also performed with glycolaldehyde as glycating agent and two different effects on protein aggregation were observed depending on HEWL concentration regime [177]. In particular, at low HEWL concentration (below $2 \mu \mathrm{M}$ ), non-cross-linking fluorescent AGEs were formed on Lys side chains, and they did not affect the protein structure but inhibit its enzymatic activity. These AGEs were having little impact on HEWL surface hydrophobicity and, therefore, a negligible effect on its aggregation propensity. Upon increasing HEWL concentration $(20-100 \mu \mathrm{M})$, the glycation mechanism was shifting toward the formation of intermolecular cross-links, which trigger a polymerization cascade involving the formation of insoluble spherical-like aggregates through a concentration-dependent nucleation mechanism [177]. Recently, a different effect on glycation mediated HEWL aggregation has been reported using MGO as glycating agent [178]. In this study it has been shown that, upon incubation with MGO for three weeks, the stress-induced aggregation of HEWL was strongly reduced. Indeed, upon thermal and chemical stress, while the non-modified HEWL was rapidly forming amyloid fibrils, the MGO-modified protein was not showing any fibril formation but only small amorphous structures. Structural analysis has shown that MGO-glycation only affects arginine residues and induces changes in tertiary structure of the protein without significantly affecting its secondary structure. The authors have hypothesized that the MGO-induced modification of HEWL arginine residues to neutral AGE adducts could be responsible for the reduced susceptibility to amyloid aggregation [178]. These results notably differ with the aggregation-modulation mechanism of ribosylated HEWL directed by hydrophobic interactions clearly showing that the mechanism underlying the aggregation of a glycated protein strongly depends on the chemical nature of the glycating agent.

\subsection{Hemoglobin}

Human hemoglobin $(\mathrm{Hb})$ has been the first glycated protein to be identified in vivo and it is widely used in diagnostics as it indicates the presence of excessive sugar in the bloodstream $[179,180]$. Indeed, the subfraction $\mathrm{HbA1c}$, glycated at the amino-terminal valine residue of the $\beta$ chain, may be significant with increased level of blood glucose over prolonged periods of time and, for this reason, is considered an important biomolecular marker for evaluating long term control of diabetes.

$\mathrm{Hb}$ can be glycated by glucose, fructose, and methylglyoxal [181-183], and several studies have been published on glycation-induced structural and functional modifications of $\mathrm{Hb}[182,184,185]$. In particular, it has been shown that the glucose-induced glycation (both in vitro and in vivo) promotes iron release and enhances free-radical mediated oxidative stress [181]. Exposure to fructose directly promotes strong conformational changes in $\mathrm{Hb}$ driving the native $\alpha$-helical structure into non-native often $\beta$-sheet rich structure, favors the unfolded conformation and stimulates $\mathrm{Hb}$ aggregation $[182,186,187]$. Glyoxal is the more efficient glycating agents so far tested for $\mathrm{Hb}$ and it has been shown to promote considerable retention of secondary structure and loss of tertiary structure as suggested by increased heme exposure and reduced hydrophobic surface. Glycation by glyoxal also promotes the formation of partially unfolded molecules that are aggregation-prone thus inducing aggregation in $\mathrm{Hb}[188,189]$. The overall data suggest that glycation modifications of $\mathrm{Hb}$ might strongly modulate the amyloidogenic properties of this protein, and this could play a key role in accumulating additional amyloid during diabetes progression.

\section{Conclusions and Perspectives}

Protein glycation is a spontaneous age-dependent post-translational modification that can affect the structure and function of several proteins. Glycation reaction is strongly affected by concentration and reactivity of the glycating agent (reducing sugar, carbonyl compound), oxidative conditions, number of glycation sites, and their exposure in the 
protein structure. In this respect, the effect of glycation on the protein structure strongly depends on the exposure of glycating sites in the protein structure, the type of AGEs formed, and the environmental conditions. The data presented for the different model proteins clearly suggest that glycation affects the aggregation properties of polypeptides unevenly; it stimulates amyloid aggregation in some proteins, whereas it slows down the process for other proteins. Indeed, glycation is shown to accelerate the aggregation rate in some model proteins as A $\beta$-peptide in the double lysine CEL-AGE, IAPP in the presence of glucose and hemoglobin in the presence of fructose and GO $[60,120,182,186]$. At the same time, glycation can inhibit amyloid aggregation as in IAPP with MGO; in $\alpha$-synuclein with D-ribose, MGO, and GO; in insulin with D-ribose and MGO; and in SOD1 with glucose, Dribose, GO, and MGO $[85,86,107,108,156,158,182,186]$. In addition, glycation has been also shown to promote amyloid aggregation in natively folded proteins as in human albumin in the presence of glucose, D-ribose, MGO, and GO [126-128,136,138]. The different effect can be ascribed both to the type of AGE formed and, also, to the molecular mechanisms underlying the aggregation process of the protein involved. Indeed, being a post-translational modification, glycation to specific residues can affect amyloid aggregation and the related cytotoxicity if the residues or their microenvironment are directly involved in the amyloid formation. In addition, protein glycation seems to strongly stabilize protein aggregates make them more difficult to remove from the proteasome system.

As oxidative stress is a triggering factor both in the glycation reaction and in the amyloid formation and induced toxicity, a potential therapeutic strategy for amyloid diseases could involve the use of molecules with antioxidant activity. In this respect, much attention has been paid to natural compounds, such as polyphenols, well known for their antioxidants and anti-inflammatory properties, able to prevent/protect by neurodegenerative diseases [190-196]. Several studies have suggested that natural phenolic compounds can interfere both with protein glycation and with the amyloid aggregation process of several model proteins [194,197-206]. In this context, polyphenols could represent an efficient additional therapy capable of acting on several mechanisms common to the pathologies of diabetes and amyloidosis simultaneously. They also have the advantage of being naturally found in the diet, so that their therapeutic implementation can be through a dietary alteration or nutritional supplements, which is more cost-effective, easier to implement, socially acceptable, and generally safer.

Author Contributions: C.I. writing—original draft preparation; C.I. and I.S. writing—review and editing; C.I. funding acquisition. All authors have read and agreed to the published version of the manuscript.

Funding: This research was funded by Italian Ministry of University and Research, Program "Giovani Ricercatori Rita Levi Montalcini".

Conflicts of Interest: The authors declare no conflict of interest. The funders had no role in the interpretation of data and in the writing of the manuscript.

\section{References}

1. Deuschl, G.; Beghi, E.; Fazekas, F.; Varga, T.; Christoforidi, A.K.; Sipido, E.; Bassetti, C.L.; Vos, T.; Feigin, V.L. The burden of neurological diseases in Europe: An analysis for the Global Burden of Disease Study. Lancet Public Health 2020, 5, e551-e567. [CrossRef]

2. Gerovska, D.; Irizar, H.; Otaegi, D.; Ferrer, I.; De Munain, A.L.; Araúzo-Bravo, M.J. Genealogy of the neurodegenerative diseases based on a meta-analysis of age-stratified incidence data. Sci. Rep. 2020, 10, 18923. [CrossRef]

3. Chiti, F.; Dobson, C.M. Protein Misfolding, Amyloid Formation, and Human Disease: A Summary of Progress over the Last Decade. Annu. Rev. Biochem. 2017, 86, 27-68. [CrossRef]

4. Sweeney, P.; Park, H.; Baumann, M.; Dunlop, J.; Frydman, J.; Kopito, R.; McCampbell, A.; Leblanc, G.; Venkateswaran, A.; Nurmi, A.; et al. Protein misfolding in neurodegenerative diseases: Implications and strategies. Transl. Neurodegener. 2017, 6, 1-13. [CrossRef]

5. Grochowska, K.M.; Yuanxiang, P.; Bär, J.; Raman, R.; Brugal, G.; Sahu, G.; Schweizer, M.; Bikbaev, A.; Schilling, S.; DeMuth, H.; et al. Posttranslational modification impact on the mechanism by which amyloid- $\beta$ induces synaptic dysfunction. EMBO Rep. 2017, 18, 962-981. [CrossRef] 
6. Schaffert, L.-N.; Carter, W.G. Do Post-Translational Modifications Influence Protein Aggregation in Neurodegenerative Diseases: A Systematic Review. Brain Sci. 2020, 10, 232. [CrossRef]

7. Culberson, J. Clinical Aspects of Glucose Metabolism and Chronic Disease. Prog. Mol. Biol. Transl. Sci. 2017, 146, 1-11. [CrossRef]

8. Rabbani, N.; Thornalley, P.J. Protein glycation-Biomarkers of metabolic dysfunction and early-stage decline in health in the era of precision medicine. Redox Biol. 2021, 26, 101920. [CrossRef]

9. Miyata, T.; Oda, O.; Inagi, R.; Iida, Y.; Araki, N.; Yamada, N.; Horiuchi, S.; Taniguchi, N.; Maeda, K.; Kinoshita, T. beta 2Microglobulin modified with advanced glycation end products is a major component of hemodialysis-associated amyloidosis. J. Clin. Investig. 1993, 92, 1243-1252. [CrossRef]

10. Münch, G.; Lüth, H.; Wong, A.; Arendt, T.; Hirsch, E.; Ravid, R.; Riederer, P. Crosslinking of alpha-synuclein by advanced glycation endproducts-An early pathophysiological step in Lewy body formation? J. Chem. Neuroanat. 2000, 20, $253-257$. [CrossRef]

11. Kikuchi, S.; Ogata, A.; Shinpo, K.; Moriwaka, F.; Fujii, J.; Taniguchi, N.; Tashiro, K. Detection of an Amadori product, 1-hexitollysine, in the anterior horn of the amyotrophic lateral sclerosis and spinobulbar muscular atrophy spinal cord: Evidence for early involvement of glycation in motoneuron diseases. Acta Neuropathol. 2000, 99, 63-66. [CrossRef] [PubMed]

12. Lüth, H.-J.; Ogunlade, V.; Kuhla, B.; Kientsch-Engel, R.; Stahl, P.; Webster, J.; Arendt, T.; Münch, G. Age- and Stage-dependent Accumulation of Advanced Glycation End Products in Intracellular Deposits in Normal and Alzheimer's Disease Brains. Cereb. Cortex 2005, 15, 211-220. [CrossRef] [PubMed]

13. Seo, J.-W.; Lee, K.-J. Post-translational Modifications and Their Biological Functions: Proteomic Analysis and Systematic Approaches. J. Biochem. Mol. Biol. 2004, 37, 35-44. [CrossRef] [PubMed]

14. Lima, M.; Baynes, J.W. Glycation. In Encyclopedia of Biological Chemistry, 2nd ed.; Lennarz, W.J., Lane, M.D., Eds.; Academic Press: Cambridge, MA, USA, 2013; pp. 405-411. [CrossRef]

15. Monnier, V.M.; The DCCT/EDIC Research Group; Sun, W.; Gao, X.; Sell, D.R.; Cleary, A.P.; Lachin, J.M.; Genuth, S. Skin collagen advanced glycation endproducts (AGEs) and the long-term progression of sub-clinical cardiovascular disease in type 1 diabetes. Cardiovasc. Diabetol. 2015, 14, 118. [CrossRef]

16. Ulrich, P. Protein Glycation, Diabetes, and Aging. Recent Prog. Horm. Res. 2001, 56, 1-21. [CrossRef] [PubMed]

17. Thorpe, S.R.; Baynes, J.W. Maillard reaction products in tissue proteins: New products and new perspectives. Amino Acids 2003, 25, 275-281. [CrossRef]

18. Perrone, A.; Giovino, A.; Benny, J.; Martinelli, F. Advanced Glycation End Products (AGEs): Biochemistry, Signaling, Analytical Methods, and Epigenetic Effects. Oxidative Med. Cell. Longev. 2020, 2020, 3818196. [CrossRef]

19. Wolff, S.P.; Dean, R.T. Glucose autoxidation and protein modification. The potential role of 'autoxidative glycosylation' in diabetes. Biochem. J. 1987, 245, 243-250. [CrossRef]

20. Thornalley, P.J.; Langborg, A.; Minhas, H.S. Formation of glyoxal, methylglyoxal and 3-deoxyglucosone in the glycation of proteins by glucose. Biochem. J. 1999, 344, 109-116. [CrossRef] [PubMed]

21. Luers, L.; Rysiewski, K.; Dumpitak, C.; Birkmann, E. Kinetics of Advanced Glycation End Products Formation on Bovine Serum Albumin with Various Reducing Sugars and Dicarbonyl Compounds in Equimolar Ratios. Rejuvenation Res. 2012, 15, 201-205. [CrossRef]

22. Vlassara, H. Advanced Glycation in Health and Disease: Role of the Modern Environment. Ann. N. Y. Acad. Sci. 2005, 1043, 452-460. [CrossRef] [PubMed]

23. Uchiki, T.; Weikel, K.A.; Jiao, W.; Shang, F.; Caceres, A.; Pawlak, D.; Handa, J.T.; Brownlee, M.; Nagaraj, R.; Taylor, A. Glycationaltered proteolysis as a pathobiologic mechanism that links dietary glycemic index, aging, and age-related disease (in nondiabetics). Aging Cell 2012, 11, 1-13. [CrossRef]

24. Pasupulati, A.K.; Chitra, P.S.; Reddy, G.B. Advanced glycation end products mediated cellular and molecular events in the pathology of diabetic nephropathy. Biomol. Concepts 2016, 7, 293-309. [CrossRef] [PubMed]

25. Klein, R.; Horak, K.; Lee, K.E.; Danforth, L.; Cruickshanks, K.J.; Tsai, M.Y.; Gangnon, R.E.; Klein, B.E. The Relationship of Serum Soluble Receptor for Advanced Glycation End Products (sRAGE) and Carboxymethyl Lysine (CML) to the Incidence of Diabetic Nephropathy in Persons With Type 1 Diabetes. Diabetes Care 2017, 40, e117-e119. [CrossRef]

26. Bastos, D.H.M.; Gugliucci, A. Contemporary and controversial aspects of the Maillard reaction products. Curr. Opin. Food Sci. 2015, 1, 13-20. [CrossRef]

27. Takizawa, N.; Takada, K.; Ohkawa, K. Inhibitory Effect of Nonenzymatic Glycation on Ubiquitination and Ubiquitin-Mediated Degradation of Lysozyme. Biochem. Biophys. Res. Commun. 1993, 192, 700-706. [CrossRef]

28. Finley, D. Recognition and Processing of Ubiquitin-Protein Conjugates by the Proteasome. Annu. Rev. Biochem. 2009, 78, 477-513. [CrossRef] [PubMed]

29. Sun, F.; Suttapitugsakul, S.; Xiao, H.; Wu, R. Comprehensive Analysis of Protein Glycation Reveals Its Potential Impacts on Protein Degradation and Gene Expression in Human Cells. J. Am. Soc. Mass Spectrom. 2019, 30, 2480-2490. [CrossRef]

30. Hartl, F.U. Protein Misfolding Diseases. Annu. Rev. Biochem. 2017, 86, 21-26. [CrossRef]

31. Soto, C.; Pritzkow, S. Protein misfolding, aggregation, and conformational strains in neurodegenerative diseases. Nat. Neurosci. 2018, 21, 1332-1340. [CrossRef]

32. Knowles, T.; Vendruscolo, M.; Dobson, C.M. The amyloid state and its association with protein misfolding diseases. Nat. Rev. Mol. Cell Biol. 2014, 15, 384-396. [CrossRef] 
33. Fitzpatrick, A.W.; Saibil, H.R. Cryo-EM of amyloid fibrils and cellular aggregates. Curr. Opin. Struct. Biol. $2019,58,34-42$. [CrossRef]

34. Serpell, L.C. Alzheimer's amyloid fibrils: Structure and assembly. Biochim. Biophys. Acta 2000, 1502, 16-30. [CrossRef]

35. Soto, C.; Estrada, L.D. Protein Misfolding and Neurodegeneration. Arch. Neurol. 2008, 65, 184-189. [CrossRef]

36. Dugger, B.N.; Dickson, D.W. Pathology of Neurodegenerative Diseases. Cold Spring Harb. Perspect. Biol. 2017, 9, a028035. [CrossRef]

37. Dobson, C.M. Protein folding and misfolding. Nature 2003, 426, 884-890. [CrossRef] [PubMed]

38. Baldwin, A.J.; Knowles, T.; Tartaglia, G.G.; Fitzpatrick, A.W.; Devlin, G.L.; Shammas, S.L.; Waudby, C.A.; Mossuto, M.F.; Meehan, S.; Gras, S.; et al. Metastability of Native Proteins and the Phenomenon of Amyloid Formation. J. Am. Chem. Soc. 2011, 133, 14160-14163. [CrossRef] [PubMed]

39. De Simone, A.; Dhulesia, A.; Soldi, G.; Vendruscolo, M.; Hsu, S.-T.D.; Chiti, F.; Dobson, C.M. Experimental free energy surfaces reveal the mechanisms of maintenance of protein solubility. Proc. Natl. Acad. Sci. USA 2011, 108, 21057-21062. [CrossRef] [PubMed]

40. Fabian, P.; Banach, M.; Stapor, K.; Konieczny, L.; Ptak-Kaczor, M.; Roterman, I. The Structure of Amyloid Versus the Structure of Globular Proteins. Int. J. Mol. Sci. 2020, 21, 4683. [CrossRef] [PubMed]

41. Donnarumma, F.; Emendato, A.; Leone, S.; Ercole, C.; D’Errico, G.; Picone, D. Salt Modulated Fibrillar Aggregation of the Sweet Protein MNEI in Aqueous Solution. J. Solut. Chem. 2018, 47, 939-949. [CrossRef]

42. Chiti, F.; Webster, P.; Taddei, N.; Clark, A.; Stefani, M.; Ramponi, G.; Dobson, C.M. Designing conditions for in vitro formation of amyloid protofilaments and fibrils. Proc. Natl. Acad. Sci. USA 1999, 96, 3590-3594. [CrossRef] [PubMed]

43. Ramirez-Alvarado, M.; Merkel, J.S.; Regan, L. A systematic exploration of the influence of the protein stability on amyloid fibril formation in vitro. Proc. Natl. Acad. Sci. USA 2000, 97, 8979-8984. [CrossRef]

44. Sicorello, A.; Torrassa, S.; Soldi, G.; Gianni, S.; Travaglini-Allocatelli, C.; Taddei, N.; Relini, A.; Chiti, F. Agitation and High Ionic Strength Induce Amyloidogenesis of a Folded PDZ Domain in Native Conditions. Biophys. J. 2009, 96, 2289-2298. [CrossRef] [PubMed]

45. Vettore, N.; Buell, A.K. Thermodynamics of amyloid fibril formation from chemical depolymerization. Phys. Chem. Chem. Phys. 2019, 21, 26184-26194. [CrossRef] [PubMed]

46. Delfi, M.; Leone, S.; Emendato, A.; Ami, D.; Borriello, M.; Natalello, A.; Iannuzzi, C.; Picone, D. Understanding the self-assembly pathways of a single chain variant of monellin: A first step towards the design of sweet nanomaterials. Int. J. Biol. Macromol. 2020, 152, 21-29. [CrossRef]

47. Jucker, M.; Walker, L.C. Self-propagation of pathogenic protein aggregates in neurodegenerative diseases. Nature 2013, 501, 45-51. [CrossRef]

48. Halliday, M.; Radford, H.; Mallucci, G.R. Prions: Generation and Spread versus Neurotoxicity. J. Biol. Chem. 2014, 289, 19862-19868. [CrossRef]

49. Gonzalez-Garcia, M.; Fusco, G.; De Simone, A. Membrane Interactions and Toxicity by Misfolded Protein Oligomers. Front. Cell Dev. Biol. 2021, 9, 642623. [CrossRef]

50. Chen, G.-F.; Xu, T.; Yan, Y.; Zhou, Y.-R.; Jiang, Y.; Melcher, K.; Xu, H.E. Amyloid beta: Structure, biology and structure-based therapeutic development. Acta Pharmacol. Sin. 2017, 38, 1205-1235. [CrossRef]

51. Nirmalraj, P.N.; List, J.; Battacharya, S.; Howe, G.; Xu, L.; Thompson, D.; Mayer, M. Complete aggregation pathway of amyloid $\beta$ (1-40) and (1-42) resolved on an atomically clean interface. Sci. Adv. 2020, 6, eaaz6014. [CrossRef]

52. Vitek, M.P.; Bhattacharya, K.; Glendening, J.M.; Stopa, E.; Vlassara, H.; Bucala, R.; Manogue, K.; Cerami, A. Advanced glycation end products contribute to amyloidosis in Alzheimer disease. Proc. Natl. Acad. Sci. USA 1994, 91, 4766-4770. [CrossRef]

53. Li, X.-H.; Du, L.-L.; Cheng, X.-S.; Jiang, X.; Zhang, Y.; Lv, B.-L.; Liu, R.; Wang, J.-Z.; Zhou, X.-W. Glycation exacerbates the neuronal toxicity of $\beta$-amyloid. Cell Death Dis. 2013, 4, e673. [CrossRef]

54. Xu, W.L.; von Strauss, E.; Qiu, C.X.; Winblad, B.; Fratiglioni, L. Uncontrolled diabetes increases the risk of Alzheimer's disease: A population-based cohort study. Diabetologia 2009, 52, 1031-1039. [CrossRef]

55. Takeda, S.; Sato, N.; Uchio-Yamada, K.; Sawada, K.; Kunieda, T.; Takeuchi, D.; Kurinami, H.; Shinohara, M.; Rakugi, H.; Morishita, R. Diabetes-accelerated memory dysfunction via cerebrovascular inflammation and Abeta deposition in an Alzheimer mouse model with diabetes. Proc. Natl. Acad. Sci. USA 2010, 107, 7036-7041. [CrossRef]

56. Han, W.; Li, C. Linking type 2 diabetes and Alzheimer's disease. Proc. Natl. Acad. Sci. USA 2010, 107, 6557-6558. [CrossRef] [PubMed]

57. Yang, Y.; Song, W. Molecular links between Alzheimer's disease and diabetes mellitus. Neuroscience 2013, 250, 140-150. [CrossRef]

58. Kong, Y.; Wang, F.; Wang, J.; Liu, C.; Zhou, Y.; Xu, Z.; Zhang, C.; Sun, B.; Guan, Y. Pathological Mechanisms Linking Diabetes Mellitus and Alzheimer's Disease: The Receptor for Advanced Glycation End Products (RAGE). Front. Aging Neurosci. 2020, 12, 217. [CrossRef] [PubMed]

59. Jana, A.K.; Batkulwar, K.B.; Kulkarni, M.J.; Sengupta, N. Glycation induces conformational changes in amyloid- $\beta$ peptide and enhances its aggregation propensity: Molecular insights. Phys. Chem. Chem. Phys. 2016, 18, 31446-31458. [CrossRef] [PubMed]

60. Ng, J.; Kaur, H.; Collier, T.; Chang, K.; Brooks, A.E.S.; Allison, J.R.; Brimble, M.A.; Hickey, A.; Birch, N.P. Site-specific glycation of A $\beta 1-42$ affects fibril formation and is neurotoxic. J. Biol. Chem. 2019, 294, 8806-8818. [CrossRef] 
61. Emendato, A.; Milordini, G.; Zacco, E.; Sicorello, A.; Piaz, F.D.; Guerrini, R.; Thorogate, R.; Picone, D.; Pastore, A. Glycation affects fibril formation of A $\beta$ peptides. J. Biol. Chem. 2018, 293, 13100-13111. [CrossRef]

62. Kayed, R.; Head, E.; Thompson, J.L.; McIntire, T.M.; Milton, S.C.; Cotman, C.W.; Glabe, C.G. Common Structure of Soluble Amyloid Oligomers Implies Common Mechanism of Pathogenesis. Science 2003, 300, 486-489. [CrossRef]

63. Stefani, M. Structural features and cytotoxicity of amyloid oligomers: Implications in Alzheimer's disease and other diseases with amyloid deposits. Prog. Neurobiol. 2012, 99, 226-245. [CrossRef] [PubMed]

64. Shea, D.; Hsu, C.-C.; Bi, T.; Paranjapye, N.; Childers, M.C.; Cochran, J.; Tomberlin, C.P.; Wang, L.; Paris, D.; Zonderman, J.; et al. $\alpha$-Sheet secondary structure in amyloid $\beta$-peptide drives aggregation and toxicity in Alzheimer's disease. Proc. Natl. Acad. Sci. USA 2019, 116, 8895-8900. [CrossRef] [PubMed]

65. De, S.; Wirthensohn, D.C.; Flagmeier, P.; Hughes, C.; Aprile, F.A.; Ruggeri, F.S.; Whiten, D.R.; Emin, D.; Xia, Z.; Varela, J.A.; et al. Different soluble aggregates of $\mathrm{A} \beta 42$ can give rise to cellular toxicity through different mechanisms. Nat. Commun. 2019, 10, 1541. [CrossRef]

66. Dahlgren, K.N.; Manelli, A.M.; Stine, W.B.; Baker, L.; Krafft, G.A.; LaDu, M.J. Oligomeric and Fibrillar Species of Amyloid-Beta Peptides Differentially Affect Neuronal Viability. J. Biol. Chem. 2002, 277, 32046-32053. [CrossRef]

67. Sakono, M.; Zako, T. Amyloid oligomers: Formation and toxicity of Abeta oligomers. FEBS J. 2010, 277, 1348-1358. [CrossRef] [PubMed]

68. Julien, C.; Tomberlin, C.; Roberts, C.M.; Akram, A.; Stein, G.H.; Silverman, M.A.; Link, C.D. In vivo induction of membrane damage by $\beta$-amyloid peptide oligomers. Acta Neuropathol. Commun. 2018, 6, 131. [CrossRef]

69. Lue, L.-F.; Walker, D.G.; Brachova, L.; Beach, T.G.; Rogersa, J.; Schmidt, A.M.; Stern, D.M.; Du Yan, S. Involvement of Microglial Receptor for Advanced Glycation Endproducts (RAGE) in Alzheimer's Disease: Identification of a Cellular Activation Mechanism. Exp. Neurol. 2001, 171, 29-45. [CrossRef]

70. Miller, M.C.; Tavares, R.; Johanson, C.E.; Hovanesian, V.; Donahue, J.E.; Gonzalez, L.; Silverberg, G.D.; Stopa, E.G. Hippocampal RAGE immunoreactivity in early and advanced Alzheimer's disease. Brain Res. 2008, 1230, 273-280. [CrossRef]

71. Fernàndez-Busquets, X.; Ponce, J.; Bravo, R.; Arimon, M.; Martianez, T.; Gella, A.; Cladera, J.; Durany, N. Modulation of Amyloid Beta Peptide1-42 Cytotoxicity and Aggregation in Vitro by Glucose and Chondroitin Sulfate. Curr. Alzheimer Res. 2010, 7, 428-438. [CrossRef]

72. Spillantini, M.G.; Crowther, R.A.; Jakes, R.; Hasegawa, M.; Goedert, M. Alpha-Synuclein in filamentous inclusions of Lewy bodies from Parkinson's disease and dementia with Lewy bodies. Proc. Natl. Acad. Sci. USA 1998, 95, 6469-6473. [CrossRef] [PubMed]

73. De Oliveira, G.A.P.; Silva, J.L. Alpha-synuclein stepwise aggregation reveals features of an early onset mutation in Parkinson's disease. Commun. Biol. 2019, 2, 374. [CrossRef]

74. Fujiwara, H.; Hasegawa, M.; Dohmae, N.; Kawashima, A.; Masliah, E.; Goldberg, M.S.; Shen, J.; Takio, K.; Iwatsubo, T. Alpha-Synuclein is phosphorylated in synucleinopathy lesions. Nat. Cell Biol. 2002, 4, 160-164. [CrossRef]

75. Dorval, V.; Fraser, P.E. Small Ubiquitin-like Modifier (SUMO) Modification of Natively Unfolded Proteins Tau and alpha-Synuclein. J. Biol. Chem. 2006, 281, 9919-9924. [CrossRef] [PubMed]

76. Shaikh, S.; Nicholson, L.F. Advanced glycation end products induce in vitro cross-linking of alpha-synuclein and accelerate the process of intracellular inclusion body formation. J. Neurosci. Res. 2008, 86, 2071-2082. [CrossRef] [PubMed]

77. Miranda, H.V.; Szegő, É.M.; Oliveira, L.M.A.; Breda, C.; Darendelioglu, E.; De Oliveira, R.M.; Ferreira, D.G.; Gomes, M.A.; Rott, R.; Oliveira, M.; et al. Glycation potentiates $\alpha$-synuclein-associated neurodegeneration in synucleinopathies. Brain 2017, 140, 1399-1419. [CrossRef]

78. Oueslati, A.; Fournier, M.; Lashuel, H.A. Role of post-translational modifications in modulating the structure, function and toxicity of alpha-synuclein: Implications for Parkinson's disease pathogenesis and therapies. Prog. Brain Res. 2010, 183, 115-145. [CrossRef]

79. Yue, X.; Li, H.; Yan, H.; Zhang, P.; Chang, L.; Li, T. Risk of Parkinson Disease in Diabetes Mellitus: An Updated Meta-Analysis of Population-Based Cohort Studies. Medicine 2016, 95, e3549. [CrossRef]

80. Castellani, R.; Smith, M.; Richey, G.; Perry, G. Glycoxidation and oxidative stress in Parkinson disease and diffuse Lewy body disease. Brain Res. 1996, 737, 195-200. [CrossRef]

81. Dalfó, E.; Portero-Otín, M.; Ayala, V.; Martínez, A.; Pamplona, R.; Ferrer, I. Evidence of Oxidative Stress in the Neocortex in Incidental Lewy Body Disease. J. Neuropathol. Exp. Neurol. 2005, 64, 816-830. [CrossRef]

82. Chandra, S.; Chen, X.; Rizo, J.; Jahn, R.; Südhof, T.C. A Broken Alpha-Helix in Folded Alpha-Synuclein. J. Biol. Chem. 2003, 278, 15313-15318. [CrossRef]

83. Burré, J.; Sharma, M.; Südhof, T.C. Definition of a Molecular Pathway Mediating $\alpha$-Synuclein Neurotoxicity. J. Neurosci. 2015, 35, 5221-5232. [CrossRef]

84. Fusco, G.; De Simone, A.; Arosio, P.; Vendruscolo, M.; Veglia, G.; Dobson, C.M. Structural Ensembles of Membrane-bound $\alpha$-Synuclein Reveal the Molecular Determinants of Synaptic Vesicle Affinity. Sci. Rep. 2016, 6, 27125. [CrossRef]

85. Lee, D.; Park, C.W.; Paik, S.R.; Choi, K.Y. The modification of alpha-synuclein by dicarbonyl compounds inhibits its fibril-forming process. Biochim.t Biophys. Acta 2009, 1794, 421-430. [CrossRef] [PubMed]

86. Chen, L.; Wei, Y.; Wang, X.; He, R. Ribosylation Rapidly Induces Alpha-Synuclein to Form Highly Cytotoxic Molten Globules of Advanced Glycation End Products. PLoS ONE 2010, 5, e9052. [CrossRef] 
87. Dettmer, U.; Newman, A.J.; von Saucken, V.; Bartels, T.; Selkoe, D. KTKEGV repeat motifs are key mediators of normal $\alpha$-synuclein tetramerization: Their mutation causes excess monomers and neurotoxicity. Proc. Natl. Acad. Sci. USA 2015, 112, 9596-9601. [CrossRef] [PubMed]

88. Stephens, A.D.; Zacharopoulou, M.; Moons, R.; Fusco, G.; Seetaloo, N.; Chiki, A.; Woodhams, P.J.; Mela, I.; Lashuel, H.A.; Phillips, J.J.; et al. Extent of N-terminus exposure of monomeric alpha-synuclein determines its aggregation propensity. Nat. Commun. 2020, 11, 2820. [CrossRef] [PubMed]

89. Padmaraju, V.; Bhaskar, J.J.; Rao, U.J.P.; Salimath, P.V.; Rao, K. Role of Advanced Glycation on Aggregation and DNA Binding Properties of $\alpha$-Synuclein. J. Alzheimer's Dis. 2011, 24, 211-221. [CrossRef]

90. Winner, B.; Jappelli, R.; Maji, S.K.; Desplats, P.A.; Boyer, L.; Aigner, S.; Hetzer, C.; Loher, T.; Vilar, M.; Campioni, S.; et al. In vivo demonstration that -synuclein oligomers are toxic. Proc. Natl. Acad. Sci. USA 2011, 108, 4194-4199. [CrossRef]

91. Guerrero, E.; Vasudevaraju, P.; Hegde, M.; Britton, G.B.; Rao, K.S. Recent Advances in $\alpha$-Synuclein Functions, Advanced Glycation, and Toxicity: Implications for Parkinson's Disease. Mol. Neurobiol. 2013, 47, 525-536. [CrossRef]

92. Mariño, L.; Ramis, R.; Casasnovas, R.; Ortega-Castro, J.; Vilanova, B.; Frau, J.; Adrover, M. Unravelling the effect ofN( $(\varepsilon)$ (carboxyethyl)lysine on the conformation, dynamics and aggregation propensity of $\alpha$-synuclein. Chem. Sci. 2020, 11, 3332. [CrossRef] [PubMed]

93. Dische, F.E.; Wernstedt, C.; Westermark, G.T.; Westermark, P.; Pepys, M.B.; Rennie, J.A.; Gilbey, S.G.; Watkins, P.J. Insulin as an amyloid-fibril protein at sites of repeated insulin injections in a diabetic patient. Diabetologia 1988, 31, 158-161. [CrossRef] [PubMed]

94. Okamura, S.; Hayashino, Y.; Kore-Eda, S.; Tsujii, S. Localized Amyloidosis at the Site of Repeated Insulin Injection in a Patient With Type 2 Diabetes. Diabetes Care 2013, 36, e200. [CrossRef]

95. Nagase, T.; Iwaya, K.; Iwaki, Y.; Kotake, F.; Uchida, R.; Oh-I, T.; Sekine, H.; Miwa, K.; Murakami, S.; Odaka, T.; et al. Insulinderived Amyloidosis and Poor Glycemic Control: A Case Series. Am. J. Med. 2014, 127, 450-454. [CrossRef]

96. Hua, Q.-X.; Weiss, M.A. Mechanism of insulin fibrillation: The structure of insulin under amyloidogenic conditions resembles a protein-folding intermediate. J. Biol. Chem. 2004, 279, 21449-21460. [CrossRef]

97. Smirnovas, V.; Winter, R. Revealing Different Aggregation Pathways of Amyloidogenic Proteins by Ultrasound Velocimetry. Biophys. J. 2008, 94, 3241-3246. [CrossRef]

98. Iannuzzi, C.; Borriello, M.; Portaccio, M.; Irace, G.; Sirangelo, I. Insights into Insulin Fibril Assembly at Physiological and Acidic $\mathrm{pH}$ and Related Amyloid Intrinsic Fluorescence. Int. J. Mol. Sci. 2017, 18, 2551. [CrossRef] [PubMed]

99. Hunter, S.J.; Boyd, A.C.; O’Harte, F.; McKillop, A.M.; Wiggam, M.I.; Mooney, M.H.; McCluskey, J.T.; Lindsay, J.R.; Ennis, C.N.; Gamble, R.; et al. Demonstration of Glycated Insulin in Human Diabetic Plasma and Decreased Biological Activity Assessed by Euglycemic-Hyperinsulinemic Clamp Technique in Humans. Diabetes 2003, 52, 492-498. [CrossRef]

100. Lindsay, J.R.; McKillop, A.M.; Mooney, M.H.; O'Harte, F.P.M.; Bell, P.M.; Flatt, P.R. Demonstration of increased concentrations of circulating glycated insulin in human Type 2 diabetes using a novel and specific radioimmunoassay. Diabetologia 2003, 46, 475-478. [CrossRef]

101. Nowotny, K.; Jung, T.; Höhn, A.; Weber, D.; Grune, T. Advanced Glycation End Products and Oxidative Stress in Type 2 Diabetes Mellitus. Biomolecules 2015, 5, 194-222. [CrossRef]

102. Abdel-Wahab, Y.; O'Harte, F.; Ratcliff, H.; McClenaghan, N.H.; Barnett, C.R.; Flatt, P.R. Glycation of Insulin in the Islets of Langerhans of Normal and Diabetic Animals. Diabetes 1996, 45, 1489-1496. [CrossRef]

103. Abdel-Wahab, Y.H.A.; O'Harte, F.P.M.; Boyd, A.C.; Barnett, C.R.; Flatt, P.R. Glycation of insulin results in reduced biological activity in mice. Acta Diabetol. 1997, 34, 265-270. [CrossRef]

104. Boyd, A.C.; Abdel-Wahab, Y.; McKillop, A.M.; McNulty, H.; Barnett, C.R.; O'Harte, F.P.; Flatt, P.R. Impaired ability of glycated insulin to regulate plasma glucose and stimulate glucose transport and metabolism in mouse abdominal muscle. Biochim. Biophys. Acta 2000, 1523, 128-134. [CrossRef]

105. O'Harte, F.; Højrup, P.; Barnett, C.R.; Flatt, P.R. Identification of the site of glycation of human insulin. Peptides 1996, 17, 1323-1330. [CrossRef]

106. Guedes, S.; Vitorino, R.; Domingues, M.R.M.; Amado, F.; Domingues, P. Mass spectrometry characterization of the glycation sites of bovine insulin by tandem mass spectrometry. J. Am. Soc. Mass Spectrom. 2009, 20, 1319-1326. [CrossRef] [PubMed]

107. Alavi, P.; Yousefi, R.; Amirghofran, S.; Karbalaei-Heidari, H.R.; Moosavi-Movahedi, A.A. Structural Analysis and Aggregation Propensity of Reduced and Nonreduced Glycated Insulin Adducts. Appl. Biochem. Biotechnol. 2013, 170, 623-638. [CrossRef]

108. Oliveira, A.L.M.; Lages, A.; Gomes, A.R.; Neves, H.; Família, C.; Coelho, A.V.; Quintas, A. Insulin glycation by methylglyoxal results in native-like aggregation and inhibition of fibril formation. BMC Biochem. 2011, 12, 41. [CrossRef]

109. Iannuzzi, C.; Borriello, M.; Carafa, V.; Altucci, L.; Vitiello, M.; Balestrieri, M.L.; Ricci, G.; Irace, G.; Sirangelo, I. D-ribose-glycation of insulin prevents amyloid aggregation and produces cytotoxic adducts. Biochim. Biophys. Acta 2016, 1862, 93-104. [CrossRef] [PubMed]

110. Haataja, L.; Gurlo, T.; Huang, C.J.; Butler, P.C. Islet Amyloid in Type 2 Diabetes, and the Toxic Oligomer Hypothesis. Endocr. Rev. 2008, 29, 303-316. [CrossRef]

111. Akter, R.; Cao, P.; Noor, H.; Ridgway, Z.; Tu, L.-H.; Wang, H.; Wong, A.G.; Zhang, X.; Abedini, A.; Schmidt, A.M.; et al. Islet Amyloid Polypeptide: Structure, Function, and Pathophysiology. J. Diabetes Res. 2016, 2016, 2798269. [CrossRef] 
112. Lukinius, A.; Wilander, E.; Westermark, G.T.; Engström, U.; Westermark, P. Co-localization of islet amyloid polypeptide and insulin in the B cell secretory granules of the human pancreatic islets. Diabetologia 1989, 32, 240-244. [CrossRef]

113. Westermark, P.; Andersson, A.; Westermark, G.T. Islet Amyloid Polypeptide, Islet Amyloid, and Diabetes Mellitus. Physiol. Rev. 2011, 91, 795-826. [CrossRef]

114. Cheng, B.; Gong, H.; Li, X.; Sun, Y.; Zhang, X.; Chen, H.; Liu, X.; Zheng, L.; Huang, K. Silibinin inhibits the toxic aggregation of human islet amyloid polypeptide. Biochem. Biophys. Res. Commun. 2012, 419, 495-499. [CrossRef]

115. Cao, P.; Abedini, A.; Raleigh, D.P. Aggregation of islet amyloid polypeptide: From physical chemistry to cell biology. Curr. Opin. Struct. Biol. 2013, 23, 82-89. [CrossRef]

116. Chaari, A.; Ladjimi, M. Human islet amyloid polypeptide (hIAPP) aggregation in type 2 diabetes: Correlation between intrinsic physicochemical properties of hIAPP aggregates and their cytotoxicity. Int. J. Biol. Macromol. 2019, 136, 57-65. [CrossRef]

117. Godin, E.; Nguyen, P.T.; Zottig, X.; Bourgault, S. Identification of a hinge residue controlling islet amyloid polypeptide selfassembly and cytotoxicity. J. Biol. Chem. 2019, 294, 8452-8463. [CrossRef] [PubMed]

118. Kapurniotu, A.; Bernhagen, J.; Greenfield, N.; Al-Abed, Y.; Teichberg, S.; Frank, R.W.; Voelter, W.; Bucala, R. Contribution of advanced glycosylation to the amyloidogenicity of islet amyloid polypeptide. Eur. J. Biochem. 1998, 251, 208-216. [CrossRef] [PubMed]

119. Kapurniotu, A. Amyloidogenicity and cytotoxicity of islet amyloid polypeptide. Biopolymers 2001, 60, 438-459. [CrossRef]

120. Ma, Z.; Westermark, P.; Westermark, G.T. Amyloid in Human Islets of Langerhans: Immunologic Evidence That Islet Amyloid Polypeptide Is Modified in Amyloidogenesis. Pancreas 2000, 21, 212-218. [CrossRef] [PubMed]

121. Abedini, A.; Raleigh, D.P. Destabilization of Human IAPP Amyloid Fibrils by Proline Mutations Outside of the Putative Amyloidogenic Domain: Is There a Critical Amyloidogenic Domain in Human IAPP? J. Mol. Biol. 2006, 355, 274-281. [CrossRef] [PubMed]

122. Tu, L.-H.; Raleigh, D.P. Role of Aromatic Interactions in Amyloid Formation by Islet Amyloid Polypeptide. Biochemistry 2013, 52, 333-342. [CrossRef] [PubMed]

123. Nguyen, P.T.; Zottig, X.; Sebastiao, M.; Bourgault, S. Role of Site-Specific Asparagine Deamidation in Islet Amyloid Polypeptide Amyloidogenesis: Key Contributions of Residues 14 and 21. Biochemistry 2017, 56, 3808-3817. [CrossRef] [PubMed]

124. Hsu, Y.-H.; Chen, Y.-W.; Wu, M.-H.; Tu, L.-H. Protein Glycation by Glyoxal Promotes Amyloid Formation by Islet Amyloid Polypeptide. Biophys. J. 2019, 116, 2304-2313. [CrossRef] [PubMed]

125. Milordini, G.; Zacco, E.; Percival, M.; Puglisi, R.; Piaz, F.D.; Temussi, P.; Pastore, A. The Role of Glycation on the Aggregation Properties of IAPP. Front. Mol. Biosci. 2020, 7, 104. [CrossRef] [PubMed]

126. Coussons, P.J.; Jacoby, J.; McKay, A.; Kelly, S.; Price, N.C.; Hunt, J.V. Glucose Modification of Human Serum Albumin: A Structural Study. Free. Radic. Biol. Med. 1997, 22, 1217-1227. [CrossRef]

127. Mendez, D.L.; Jensen, R.A.; McElroy, L.A.; Pena, J.M.; Esquerra, R.M. The effect of non-enzymatic glycation on the unfolding of human serum albumin. Arch. Biochem. Biophys. 2005, 444, 92-99. [CrossRef]

128. Rondeau, P.; Armenta, S.; Caillens, H.; Chesne, S.; Bourdon, E. Assessment of temperature effects on beta-aggregation of native and glycated albumin by FTIR spectroscopy and PAGE: Relations between structural changes and antioxidant properties. Arch. Biochem. Biophys. 2007, 460, 141-150. [CrossRef]

129. Wei, Y.; Chen, L.; Chen, J.; Ge, L.; He, R.Q. Rapid glycation with D-ribose induces globular amyloid-like aggregations of BSA with high cytotoxicity to SH-SY5Y cells. BMC Cell Biol. 2009, 10, 10. [CrossRef]

130. Williams, S.K.; Solenski, N.J. Enhanced vesicular ingestion of nonenzymatically glucosylated proteins by capillary endothelium. Microvasc. Res. 1984, 28, 311-321. [CrossRef]

131. Sabbatini, M.; Sansone, G.; Uccello, F.; Giliberti, A.; Conte, G.; Andreucci, V.E. Early glycosylation products induce glomerular hyperfiltration in normal rats. Kidney Int. 1992, 42, 875-881. [CrossRef]

132. Cohen, M.P. Intervention strategies to prevent pathogenetic effects of glycated albumin. Arch. Biochem. Biophys. 2003, 419, 25-30. [CrossRef]

133. Juárez, J.; López, S.G.; Cambón, A.; Taboada, P.; Mosquera, V. Influence of Electrostatic Interactions on the Fibrillation Process of Human Serum Albumin. J. Phys. Chem. B 2009, 113, 10521-10529. [CrossRef]

134. Bhattacharya, M.; Jain, N.; Mukhopadhyay, S. Insights into the Mechanism of Aggregation and Fibril Formation from Bovine Serum Albumin. J. Phys. Chem. B 2011, 115, 4195-4205. [CrossRef]

135. Pandey, N.K.; Ghosh, S.; Tripathy, D.R.; Dasgupta, S. Effect of temperature and solvent on fibrillation of human serum albumin. Protein Pept. Lett. 2015, 22, 112-118. [CrossRef] [PubMed]

136. Sattarahmady, N.; Moosavimovahedi, A.; Ahmad, F.; Hakimelahi, G.; Habibirezaei, M.; Saboury, A.; Sheibani, N. Formation of the molten globule-like state during prolonged glycation of human serum albumin. Biochim. Biophys. Acta 2007, 1770, 933-942. [CrossRef] [PubMed]

137. Jyoti; Mir, A.R.; Habib, S.; Siddiqui, S.S.; Ali, A. Moinuddin Neo-epitopes on methylglyoxal modified human serum albumin lead to aggressive autoimmune response in diabetes. Int. J. Biol. Macromol. 2016, 86, 799-809. [CrossRef] [PubMed]

138. Zhao, D.; Sheng, B.; Li, H.; Wu, Y.; Xu, D.; Li, C. Glycation from $\alpha$-dicarbonyl compounds has different effects on the heat-induced aggregation of bovine serum albumin and $\beta$-casein. Food Chem. 2021, 340, 128108. [CrossRef] 
139. Khan, M.S.; Dwivedi, S.; Priyadarshini, M.; Tabrez, S.; Siddiqui, M.; Jagirdar, H.; Al-Senaidy, A.M.; Al-Khedhairy, A.; Musarrat, J. Ribosylation of bovine serum albumin induces ROS accumulation and cell death in cancer line (MCF-7). Eur. Biophys. J. 2013, 42, 811-818. [CrossRef] [PubMed]

140. Das, A.; Basak, P.; Pramanik, A.; Majumder, R.; Ghosh, A.; Hazra, S.; Guria, M.; Bhattacharyya, M.; Banik, S.P. Ribosylation induced structural changes in Bovine Serum Albumin: Understanding high dietary sugar induced protein aggregation and amyloid formation. Heliyon 2020, 6, 05053. [CrossRef] [PubMed]

141. Tarannum, A.; Arif, Z.; Alam, K. Moinuddin Glycation, nitro-oxidation and glyco-nitro-oxidation of human serum albumin: A physico-chemical study. J. Mol. Struct. 2020, 1210. [CrossRef]

142. Gruzman, A.; Wood, W.L.; Alpert, E.; Prasad, M.D.; Miller, R.G.; Rothstein, J.D.; Bowser, R.; Hamilton, R.; Wood, T.D.; Cleveland, D.W.; et al. Common molecular signature in SOD1 for both sporadic and familial amyotrophic lateral sclerosis. Proc. Natl. Acad. Sci. USA 2007, 104, 12524-12529. [CrossRef] [PubMed]

143. Chattopadhyay, M.; Valentine, J.S. Aggregation of Copper-Zinc Superoxide Dismutase in Familial and Sporadic ALS. Antioxidants Redox Signal. 2009, 11, 1603-1614. [CrossRef]

144. Wright, G.S.A.; Antonyuk, S.V.; Hasnain, S.S. The biophysics of superoxide dismutase-1 and amyotrophic lateral sclerosis. Q. Rev. Biophys. 2019, 52, 12. [CrossRef] [PubMed]

145. Banci, L.; Bertini, I.; Durazo, A.; Girotto, S.; Gralla, E.B.; Martinelli, M.; Valentine, J.S.; Vieru, M.; Whitelegge, J.P. Metal-free superoxide dismutase forms soluble oligomers under physiological conditions: A possible general mechanism for familial ALS. Proc. Natl. Acad. Sci. USA 2007, 104, 11263-11267. [CrossRef] [PubMed]

146. Banci, L.; Bertini, I.; Boca, M.; Girotto, S.; Martinelli, M.; Valentine, J.S.; Vieru, M. SOD1 and Amyotrophic Lateral Sclerosis: Mutations and Oligomerization. PLoS ONE 2008, 3, e1677. [CrossRef]

147. Banci, L.; Bertini, I.; Boca, M.; Calderone, V.; Cantini, F.; Girotto, S.; Vieru, M. Structural and dynamic aspects related to oligomerization of apo SOD1 and its mutants. Proc. Natl. Acad. Sci. USA 2009, 106, 6980-6985. [CrossRef]

148. Karch, C.M.; Borchelt, D.R. A Limited Role for Disulfide Cross-linking in the Aggregation of Mutant SOD1 Linked to Familial Amyotrophic Lateral Sclerosis. J. Biol. Chem. 2008, 283, 13528-13537. [CrossRef]

149. Sirangelo, I.; Iannuzzi, C. The Role of Metal Binding in the Amyotrophic Lateral Sclerosis-Related Aggregation of Copper-Zinc Superoxide Dismutase. Molecules 2017, 22, 1429. [CrossRef]

150. Chou, S.M.; Wang, H.S.; Taniguchi, A.; Bucala, R. Advanced glycation endproducts in neurofilament conglomeration of motoneurons in familial and sporadic amyotrophic lateral sclerosis. Mol. Med. 1998, 4, 324-332. [CrossRef]

151. Chou, S.; Han, C.; Wang, H.; Vlassara, H.; Bucala, R. A receptor for advanced glycosylation endproducts (AGEs) is colocalized with neurofilament-bound AGEs and SOD1 in motoneurons of ALS: Immunohistochemical study. J. Neurol. Sci. 1999, 169, 87-92. [CrossRef]

152. Arai, K.; Maguchi, S.; Fujii, S.; Ishibashi, H.; Oikawa, K.; Taniguchi, N. Glycation and inactivation of human Cu-Zn-superoxide dismutase. Identification of the in vitro glycated sites. J. Biol. Chem. 1987, 262, 16969-16972. [CrossRef]

153. Sirangelo, I.; Vella, F.M.; Irace, G.; Manco, G.; Iannuzzi, C. Glycation in Demetalated Superoxide Dismutase 1 Prevents Amyloid Aggregation and Produces Cytotoxic Ages Adducts. Front. Mol. Biosci. 2016, 3, 55. [CrossRef]

154. Polykretis, P.; Luchinat, E.; Boscaro, F.; Banci, L. Methylglyoxal interaction with superoxide dismutase. Redox Biol. $2020,30,101421$. [CrossRef] [PubMed]

155. Mercado-Uribe, H.; Andrade-Medina, M.; Espinoza-Rodríguez, J.H.; Carrillo-Tripp, M.; Scheckhuber, C.Q. Analyzing structural alterations of mitochondrial intermembrane space superoxide scavengers cytochrome-c and SOD1 after methylglyoxal treatment. PLoS ONE 2020, 15, e0232408. [CrossRef] [PubMed]

156. Kang, J.H. Modification and inactivation of human Cu,Zn-superoxide dismutase by methylglyoxal. Mol. Cells 2003, 15, 194-199. [PubMed]

157. Jabeen, R.; Saleemuddin, M.; Petersen, J.; Mohammad, A. Inactivation and modification of superoxide dismutase by glyoxal: Prevention by antibodies. Biochimie 2007, 89, 311-318. [CrossRef] [PubMed]

158. Khan, M.A.; Anwar, S.; Aljarbou, A.N.; Al-Orainy, M.; Aldebasi, Y.H.; Islam, S.; Younus, H. Protective effect of thymoquinone on glucose or methylglyoxal-induced glycation of superoxide dismutase. Int. J. Biol. Macromol. 2014, 65, 16-20. [CrossRef]

159. Kawamura, N.; Ookawara, T.; Suzuki, K.; Konishi, K.; Mino, M.; Taniguchi, N. Increased glycated Cu,Zn-superoxide dismutase levels in erythrocytes of patients with insulin-dependent diabetis mellitus. J. Clin. Endocrinol. Metab. 1992, 74, 1352-1354. [CrossRef] [PubMed]

160. Pepys, M.B.; Hawkins, P.N.; Booth, D.R.; Vigushin, D.M.; Tennent, G.A.; Soutar, A.K.; Totty, N.; Nguyen, O.; Blake, C.C.F.; Terry, C.J.; et al. Human lysozyme gene mutations cause hereditary systemic amyloidosis. Nature 1993, 362, 553-557. [CrossRef]

161. Booth, D.R.; Sunde, M.; Bellotti, V.; Robinson, C.V.; Hutchinson, W.L.; Fraser, P.E.; Hawkins, P.N.; Dobson, C.M.; Radford, S.; Blake, C.C.F.; et al. Instability, unfolding and aggregation of human lysozyme variants underlying amyloid fibrillogenesis. Nature 1997, 385, 787-793. [CrossRef]

162. Canet, D.; Sunde, M.; Last, A.M.; Miranker, A.; Spencer, A.; Robinson, C.V.; Dobson, C.M. Mechanistic Studies of the Folding of Human Lysozyme and the Origin of Amyloidogenic Behavior in Its Disease-Related Variants. Biochemistry 1999, 38, 6419-6427. [CrossRef] [PubMed] 
163. Morozova-Roche, L.A.; Zurdo, J.; Spencer, A.; Noppe, W.; Receveur-Brechot, V.; Archer, D.B.; Joniau, M.; Dobson, C.M. Amyloid Fibril Formation and Seeding by Wild-Type Human Lysozyme and Its Disease-Related Mutational Variants. J. Struct. Biol. 2000, 130, 339-351. [CrossRef]

164. Sattianayagam, P.T.; Gibbs, S.D.J.; Rowczenio, D.; Pinney, J.H.; Wechalekar, A.D.; Gilbertson, J.A.; Hawkins, P.N.; Lachmann, H.J.; Gillmore, J.D. Hereditary lysozyme amyloidosis-Phenotypic heterogeneity and the role of solid organ transplantation. J. Intern. Med. 2012, 272, 36-44. [CrossRef] [PubMed]

165. Arnaudov, L.N.; de Vries, R. Thermally Induced Fibrillar Aggregation of Hen Egg White Lysozyme. Biophys. J. 2005, 88, 515-526. [CrossRef] [PubMed]

166. Cao, A.; Hu, D.; Lai, L. Formation of amyloid fibrils from fully reduced hen egg white lysozyme. Protein Sci. 2004, 13, 319-324. [CrossRef]

167. Vernaglia, B.A.; Huang, J.; Clark, E.D. Guanidine Hydrochloride Can Induce Amyloid Fibril Formation from Hen Egg-White Lysozyme. Biomacromolecules 2004, 5, 1362-1370. [CrossRef]

168. Swaminathan, R.; Ravi, V.K.; Kumar, S.; Kumar, M.V.S.; Chandra, N. Lysozyme: A model protein for amyloid research. Adv Protein Chem. Struct. Biol. 2011, 84, 63-111. [CrossRef]

169. Lapolla, A.; Fedele, D.; Aronica, R.; Baldo, L.; D'Alpaos, M.; Seraglia, R.; Traldi, P. The In Vitro Glycation of Lysozyme and the Influence of Buffer Concentration Investigated by Mass Spectrometry. Rapid Commun. Mass Spectrom. 1996, 10, 1512-1518. [CrossRef]

170. Tagami, U.; Akashi, S.; Mizukoshi, T.; Suzuki, E.; Hirayama, K. Structural studies of the Maillard reaction products of a protein using ion trap mass spectrometry. J. Mass Spectrom. 2000, 35, 131-138. [CrossRef]

171. Yeboah, F.K.; Alli, I.; Yaylayan, V.A.; Konishi, Y.; Stefanowicz, P. Monitoring glycation of lysozyme by electrospray ionization mass spectrometry. J. Agric. Food Chem. 2000, 48, 2766-2774. [CrossRef]

172. Bathaie, S.Z.; Nobakht, B.B.F.; Mirmiranpour, H.; Jafarnejad, A.; Moosavi-Nejad, S.Z. Effect of Chemical Chaperones on GlucoseInduced Lysozyme Modifications. Protein J. 2011, 30, 480-489. [CrossRef]

173. Chetyrkin, S.; Mathis, M.; Pedchenko, V.; Sanchez, O.A.; McDonald, W.H.; Hachey, D.L.; Madu, H.; Stec, D.; Hudson, B.; Voziyan, P. Glucose Autoxidation Induces Functional Damage to Proteins via Modification of Critical Arginine Residues. Biochemistry 2011, 50, 6102-6112. [CrossRef]

174. Ghosh, S.; Pandey, N.K.; Roy, A.S.; Tripathy, D.R.; Dinda, A.K.; Dasgupta, S. Prolonged Glycation of Hen Egg White Lysozyme Generates Non Amyloidal Structures. PLoS ONE 2013, 8, e74336. [CrossRef]

175. Fazili, N.A.; Naeem, A. In Vitro Hyperglycemic Condition Facilitated the Aggregation of Lysozyme via the Passage Through a Molten Globule State. Cell Biochem. Biophys. 2013, 66, 265-275. [CrossRef]

176. Adrover, M.; Mariño, L.; Sanchis, P.; Pauwels, K.; Kraan, Y.; Lebrun, P.; Vilanova, B.; Muñoz, F.; Broersen, K.; Donoso, J. Mechanistic Insights in Glycation-Induced Protein Aggregation. Biomacromolecules 2014, 15, 3449-3462. [CrossRef]

177. Mariño, L.; Aguirre, C.M.; Pauwels, K.; Vilanova, B.; Ortega-Castro, J.; Frau, J.; Donoso, J.; Adrover, M. Glycation of Lysozyme by Glycolaldehyde Provides New Mechanistic Insights in Diabetes-Related Protein Aggregation. ACS Chem. Biol. 2017, 12, 1152-1162. [CrossRef] [PubMed]

178. Banerjee, S. Methylglyoxal modification reduces the sensitivity of hen egg white lysozyme to stress-induced aggregation: Insight into the anti-amyloidogenic property of $\alpha$-dicarbonyl compound. J. Biomol. Struct. Dyn. 2020, 38, 5474-5487. [CrossRef] [PubMed]

179. Cohen, M.P.; Wu, V.-Y. Purification of glycated hemoglobin. Methods Enzymol. 1994, 231, 65-75. [CrossRef] [PubMed]

180. Miedema, K. Standardization of HbA1c and Optimal Range of Monitoring. Scand. J. Clin. Lab. Investig. 2005, $240,61-72$. [CrossRef]

181. Sen, S.; Kar, M.; Roy, A.; Chakraborti, A.S. Effect of nonenzymatic glycation on functional and structural properties of hemoglobin. Biophys. Chem. 2005, 113, 289-298. [CrossRef]

182. Bose, T.; Chakraborti, A.S. Fructose-induced structural and functional modifications of hemoglobin: Implication for oxidative stress in diabetes mellitus. Biochim. Biophys. Acta 2008, 1780, 800-808. [CrossRef] [PubMed]

183. Bose, T.; Bhattacherjee, A.; Banerjee, S.; Chakraborti, A.S. Methylglyoxal-induced modifications of hemoglobin: Structural and functional characteristics. Arch. Biochem. Biophys. 2013, 529, 99-104. [CrossRef] [PubMed]

184. Watala, C.; Gwoadzinski, K.; Małek, M. Direct evidence for the alterations in protein structure and conformation upon In vitro nonenzymatic glycosylation. Int. J. Biochem. 1992, 24, 1295-1302. [CrossRef]

185. Khoo, U.Y.; Newman, D.J.; Miller, W.K.; Price, C.P. The Influence of Glycation on the Peroxidase Activity of Haemoglobin. Eur. J. Clin. Chem. Clin. Biochem. 1994, 32, 435-440. [CrossRef] [PubMed]

186. Rahmanifar, E.; Miroliaei, M. Differential effect of biophenols on attenuation of AGE-induced hemoglobin aggregation. Int. J. Biol. Macromol. 2020, 151, 797-805. [CrossRef]

187. Bakhti, M.; Habibi-Rezaei, M.; Moosavi-Movahedi, A.; Khazaei, M. Consequential Alterations in Haemoglobin Structure upon Glycation with Fructose: Prevention by Acetylsalicylic Acid. J. Biochem. 2007, 141, 827-833. [CrossRef]

188. Iram, A.; Alam, T.; Khan, J.M.; Khan, T.A.; Khan, R.H.; Naeem, A. Molten Globule of Hemoglobin Proceeds into Aggregates and Advanced Glycated End Products. PLoS ONE 2013, 8, e72075. [CrossRef]

189. Iram, A.; Naeem, A. Detection and analysis of protofibrils and fibrils of hemoglobin: Implications for the pathogenesis and cure of heme loss related maladies. Arch. Biochem. Biophys. 2013, 533, 69-78. [CrossRef] [PubMed] 
190. Bhullar, K.S.; Rupasinghe, H.P.V. Polyphenols: Multipotent Therapeutic Agents in Neurodegenerative Diseases. Oxidative Med. Cell. Longev. 2013, 2013, 891748. [CrossRef]

191. Stefani, M.; Rigacci, S. Beneficial properties of natural phenols: Highlight on protection against pathological conditions associated with amyloid aggregation. BioFactors 2014, 40, 482-493. [CrossRef]

192. Gorzynik-Debicka, M.; Przychodzen, P.; Cappello, F.; Kuban-Jankowska, A.; Gammazza, A.M.; Knap, N.; Wozniak, M.; GorskaPonikowska, M. Potential Health Benefits of Olive Oil and Plant Polyphenols. Int. J. Mol. Sci. 2018, 19, 686. [CrossRef]

193. Silveira, A.C.; Dias, J.P.; Santos, V.M.; Oliveira, P.F.; Alves, M.G.; Rato, L.P.; Silva, B.M. The Action of Polyphenols in Diabetes Mellitus and Alzheimer's Disease: A Common Agent for Overlapping Pathologies. Curr. Neuropharmacol. 2019, 17, 590-613. [CrossRef]

194. Leri, M.; Scuto, M.; Ontario, M.L.; Calabrese, V.; Calabrese, E.J.; Bucciantini, M.; Stefani, M. Healthy Effects of Plant Polyphenols: Molecular Mechanisms. Int. J. Mol. Sci. 2020, 21, 1250. [CrossRef] [PubMed]

195. Cassidy, L.; Fernandez, F.; Johnson, J.B.; Naiker, M.; Owoola, A.G.; Broszczak, D.A. Oxidative stress in alzheimer's disease: A review on emergent natural polyphenolic therapeutics. Complement. Ther. Med. 2020, 49, 102294. [CrossRef]

196. Chen, C.; Ai, Q.-D.; Wei, Y.-H. Potential role of hydroxytyrosol in neuroprotection. J. Funct. Foods 2021, 82, 104506. [CrossRef]

197. Sadowska-Bartosz, I.; Bartosz, G. Prevention of Protein Glycation by Natural Compounds. Molecules 2015, $20,3309-3334$. [CrossRef]

198. Navarro, M.; Morales, F.J. Mechanism of reactive carbonyl species trapping by hydroxytyrosol under simulated physiological conditions. Food Chem. 2015, 175, 92-99. [CrossRef]

199. Navarro, M.; Morales, F.J. Evaluation of an olive leaf extract as a natural source of antiglycative compounds. Food Res. Int. 2017, 92, 56-63. [CrossRef] [PubMed]

200. Iannuzzi, C.; Borriello, M.; Irace, G.; Cammarota, M.; Di Maro, A.; Sirangelo, I. Vanillin Affects Amyloid Aggregation and Non-Enzymatic Glycation in Human Insulin. Sci. Rep. 2017, 7, 15086. [CrossRef]

201. Borriello, M.; Iannuzzi, C.; Sirangelo, I. Pinocembrin Protects from AGE-Induced Cytotoxicity and Inhibits Non-Enzymatic Glycation in Human Insulin. Cells 2019, 8, 385. [CrossRef]

202. Leri, M.; Oropesa-Nuñez, R.; Canale, C.; Raimondi, S.; Giorgetti, S.; Bruzzone, E.; Bellotti, V.; Stefani, M.; Bucciantini, M. Oleuropein aglycone: A polyphenol with different targets against amyloid toxicity. Biochim. Biophys. Acta 2018, 1862, 1432-1442. [CrossRef]

203. Leri, M.; Natalello, A.; Bruzzone, E.; Stefani, M.; Bucciantini, M. Oleuropein aglycone and hydroxytyrosol interfere differently with toxic A $\beta(1-42)$ aggregation. Food Chem. Toxicol. 2019, 129, 1-12. [CrossRef]

204. Fernandes, A.C.F.; Santana, Á.L.; Martins, I.M.; Moreira, D.K.T.; Macedo, J.A.; Macedo, G.A. Anti-glycation effect and the $\alpha$-amylase, lipase, and $\alpha$-glycosidase inhibition properties of a polyphenolic fraction derived from citrus wastes. Prep. Biochem. Biotechnol. 2020, 50, 794-802. [CrossRef]

205. Palazzi, L.; Leri, M.; Cesaro, S.; Stefani, M.; Bucciantini, M.; de Laureto, P.P. Insight into the molecular mechanism underlying the inhibition of $\alpha$-synuclein aggregation by hydroxytyrosol. Biochem. Pharmacol. 2020, 173, 113722. [CrossRef]

206. Sirangelo, I.; Borriello, M.; Vilasi, S.; Iannuzzi, C. Hydroxytyrosol Inhibits Protein Oligomerization and Amyloid Aggregation in Human Insulin. Int. J. Mol. Sci. 2020, 21, 4636. [CrossRef] 